\title{
INSTITUTIONAL DESIGN OF A THAYERIAN CONGRESS
}

\author{
ELIZABETH GARRETT $\dagger$
}

ADRIAN VERMEULE $\dagger \dagger$

\section{INTRODUCTION}

The United States Congress frequently deliberates upon and decides questions of constitutional interpretation, and many of those decisions are immune from subsequent judicial review, de jure or de facto. To mention only the currently prominent examples, consider Congress's exclusive responsibility under Articles I and II to define and apply the Impeachment Clauses, ${ }^{1}$ and its authority under the Twelfth Amendment to certify and count electoral votes in presidential elections. ${ }^{2}$ In such cases, legal scholars typically draw upon controversial normative theories of constitutional interpretation to assess Congress's performance. In this Essay, we join the discussion by asking whether and how Congress's interpretive capacity can be improved. But we depart from the usual approach by crafting our proposals in a manner that is resolutely agnostic as among the standard normative theories of constitutional interpretation. Our aim is to propose incremental reforms to which proponents of all the standard theories might subscribe.

Copyright (C) 2001 by Elizabeth Garrett and Adrian Vermeule.

$\dagger$ Professor of Law, University of Chicago Law School.

t† Professor of Law, University of Chicago Law School. Garrett appreciates the excellent research assistance of Leslie Danks, the invaluable help of Connie Fleischer, and the financial support of the James H. Douglas Fund for the Study of Law and Government and the Law and Government Program Endowment, both at the University of Chicago Law School. Vermeule seconds these sentiments, appreciates the financial support of the Russell J. Parsons Fund, and gives special thanks to Yun Soo Vermeule. Both authors thank Jody Freeman, Barry Friedman, Phil Frickey, Jack Goldsmith, Andrei Marmor, Tracey Meares, Eric Posner, Cass Sunstein, David Weisbach, Ernie Young, and participants at faculty workshops at the law schools of the University of Chicago, the University of San Diego, UCLA, Loyola University-Los Angeles, and Boston University for their helpful comments.

1. U.S. CONST. art. I, § 2, cl. 5; id. art. I, § 3, cl. 6-7; id. art. II, § 4.

2. U.S. CONST. amend. XII. 
This search for small-scale, consensual improvements dictates our focus on the internal mechanics of congressional deliberation, an area that is rarely explored in the constitutional law literature on congressional interpretation of the Constitution. That literature, taking its inspiration from James Bradley Thayer, ${ }^{3}$ addresses itself almost exclusively to a large-scale question of institutional choice: as between Congress and other institutions, particularly the Supreme Court, how should authority to render initial or conclusive interpretations of the Constitution be allocated ${ }^{4}$ We will pursue a different strategy by focusing not upon questions of institutional choice but upon questions of institutional design. Given some allocation of constitutional authority between Congress and the judiciary, how can the rules that structure congressional operations be arranged to produce the right quantity and quality of congressional deliberation on constitutional questions?

The justifications for this strategy are both methodological and substantive. The scholarly benefit of exploring the neglected question of institutional design is much greater than the benefit produced by another article about "Congress versus the Court." And the institutional-choice question has largely been settled, not by constitutional scholarship, but by the facts of modern government. The massive scale of the political branches relative to the judiciary-measured in resources, personnel and organizational capacities-ensures that, across a broad range of constitutional questions, the legislative process rather than the Court has de jure or de facto authority to decide constitutional questions. Consider the large domain of constitutional decisionmaking over which the Supreme Court has essentially ceded control to the political branches by articulating deferential standards of review, limits on standing and justiciability, and the politicalquestion doctrine. Impeachments and many issues involving electoral processes generally lie within this domain, and other questions do as well. ${ }^{5}$ In general, we will focus our discussion on these areas of constitutional law, rather than on areas subject to judicial review.

3. James Bradley Thayer, The Origin and Scope of the American Doctrine of Constitutional Law, 7 HARV. L. REV. 129, 156 (1893) (arguing that judges should defer heavily to legislative interpretations of the Constitution).

4. For a recent example, see MARK TUSHNEt, TAKING THE CONSTITUTION AWAY FROM THE COURTS (1999).

5. See infra notes 22-37 and accompanying text (listing areas in which the congressional determination of constitutional questions is not subject to judicial review). 
Our recommendations for institutional design produce a set of structural proposals intended to improve Congress's deliberations and decisions concerning constitutional issues. These proposals draw upon Congress's recent experience with procedural frameworks like the congressional budget process, constitutional points of order in the Senate, and legislative rules in the Unfunded Mandates Reform Act. ${ }^{6}$ We identify and explain institutional design improvements in four areas: producing and disseminating information; developing expert congressional staff; restructuring congressional committees; and implementing rules to shape floor consideration.

The discussion is structured as follows. Part I explains the institutional-design strategy and defines criteria for assessing competing design proposals. Part II describes and justifies our substantive proposals. Part III concludes by considering the time frame within which such proposals might be adopted.

\section{InSTITUTIONAL CHOICE, INSTITUTIONAL DESIGN, AND THE THAYERIAN CONGRESS}

In this part we detail our assumptions, define our aims, and situate our project against the background of the relevant literatures in constitutional law, public choice, and empirical political science. Section A explains the idea of a Thayerian Congress and justifies the institutional-design strategy we will pursue. Section B explains our assumptions about legislators' behavior. Section $\mathrm{C}$ gives more precise content to the goal of improving Congress's constitutional performance.

\section{A. Toward a Structured Thayerian Congress}

James Bradley Thayer's 1892 address on "The Origin and Scope of the American Doctrine of Constitutional Law" provides the starting point for most subsequent discussion of Congress's capacities as a constitutional interpreter. Thayer argued that judges should employ a rational-basis standard for reviewing congressional determinations of constitutional questions and gave two principal reasons for this position. ${ }^{8}$ First, many constitutional questions encompass not merely technical legal issues, but instead large questions of constitu-

\footnotetext{
6. Pub. L. No. 104-4, 109 Stat. 48 (1995) (codified as amended at 2 U.S.C. $\S \S 1501-1504$ (Supp. 2000))

7. Thayer, supra note 3, at 129-56.

8. Id.
} 
tional policy and politics that legislators are better suited to decide than judges. ${ }^{9}$ Second, aggressive judicial review of congressional determinations would encourage Congress to slough its constitutional responsibilities onto the courts, weakening the culture of representative democracy. ${ }^{10} \mathrm{~A}$ "Thayerian" Congress, accordingly, is a Congress that has a great deal of responsibility for deciding constitutional questions.

For present purposes, the most important feature of Thayer's analysis is that it is solely devoted to institutional choice, including dynamic analysis of the consequences of constitutional interaction between branches, but it says very little about institutional design. Institutional choice asks which social tasks should be allocated to which institutions, holding the design of those institutions constant; institutional design asks what internal structure and decision rules institutions should have, holding the allocation of social tasks across institutions constant. Both institutional choice and institutional design are necessary components of normative constitutional analysis. Thayer, however, ignores the design question. Thayer's Congress is boneless; it lacks any internal structure, appearing solely as a stage backdrop against which individual legislator-statesmen act.

There is nothing necessarily objectionable about this reconstructed version of Thayer's project, so far as it goes. Although a fully specified constitutional theory would answer institutional-choice questions and institutional-design questions simultaneously, calibrating the resulting prescriptions with one another, no particular project need answer all of the relevant questions at once. Something must be held constant to provide a starting point, and we can understand Thayer as simply bracketing design questions in the expectation that subsequent analysis would take them up, given a set of provisional conclusions on the institutional-choice question.

That subsequent analysis is exactly what we propose to do here. Our project is to provide the internal structure for Thayer's Congress - to evaluate congressional institutions and procedures with a view to improving Congress's constitutional performance. For two reasons, this appears a more promising avenue than continued pursuit of the institutional-choice question.

The first reason is that the institutional-choice literature has progressed far enough that a switch to institutional-design questions

9. Id.

10. $I d$. 
should now produce greater intellectual returns. The modern constitutional law literature is centrally concerned with the allocation of constitutional decisionmaking authority across the institutions of the national government. This is a principal theme of important works by Bickel, ${ }^{11}$ Ely, ${ }^{12}$ and Sunstein, ${ }^{13}$ among others. By contrast, that literature has barely begun to explore the institutional-design question. Consider Paul Brest's famous article on the "conscientious" legislator's responsibility in constitutional interpretation. ${ }^{14}$ Brest addresses his advice to an abstract individual legislator who apparently considers constitutional questions in an institutional vacuum. Like Thayer, Brest shows little awareness that the power of legislators is collective rather than individual; one senator acting alone has less formal legal authority than does a police officer, for example. Consequently, legislators work within a collective institutional structure that determines their performance as constitutional interpreters and decisionmakers. The design of that institutional structure more powerfully determines Congress's interpretive capacities than does any individual legislator's conscience.

To be sure, the institutional-design question is helpfully addressed in the extensive public-choice literature on legislative voting rules, committee structure, and other topics, and in the related constitutional choice literature stemming from Buchanan and Tullock. ${ }^{15}$ While this literature is useful, it has limitations that undermine its significance for normative constitutional theory. A significant proportion of this literature works on a blank canvas, asking about major structural choices such as the choice between unicameralism and bi-

11. See generally AleXander M. Bickel, The Least Dangerous Branch (1962) (examining the scope of judicial review and the power of the United States Supreme Court).

12. See generally John Hart Ely, Democracy and Distrust: A TheOry of Judicial REVIEW (1980) (suggesting a process-based theory of judicial review).

13. See generally CASS R. Sunstein, OnE CASE AT A TIME (1999) (arguing for a minimalist form of judicial review).

14. Paul Brest, The Conscientious Legislator's Guide to Constitutional Interpretation, 27 STAN. L. REV. 585 (1975).

15. See generally JAMES M. Buchanan \& GORdON Tullock, THE CAlculus of CONSENT: LOGICAL Foundations of CONSTITUTIONAL Democracy (1967) (analyzing the calculus of rational individuals when faced with constitutional choice). For descriptions of relevant public-choice literature, see generally WiLliam N. EsKridge, JR., PhILIP P. FriCKEY \& Elizabeth Garrett, CASES AND MAterials on Legislation: STATUTES AND THE Creation of Public Policy ch. 1 (3d ed. forthcoming 2001); Daniel A. Farber \& Philip P. FRICKEY, LAW AND PUBLIC CHOICE: A CRITICAL INTRODUCTION (1991) (reviewing the body of public-choice literature and examining its applications); MAXWELL L. STEARNS, PUbLiC CHOICE AND PUBlic LAw: ReAdings AND COMMENTARY (1997) (presenting an anthology of public-choice literature). 
cameralism, between majority and supermajority voting rules, and (with respect to the selection of the legislators themselves) the choice between plurality voting and proportional representation. ${ }^{16}$ As discussed below, however, we confine ourselves to incremental proposals, on the assumption that most of the large structural choices about Congress are irrevocably fixed and that any design improvements that are practically attainable will come only at the margins. Relatedly, because of its focus on constitutional creation from the ground up, much of the public-choice literature fails to take constitutional interpretation seriously as a distinct task that legislators might perform more or less successfully under alternative institutional designs. By contrast, the most directly useful literature for our purposes is a small set of political-science research on the relative capacities of different congressional committees as constitutional interpreters and decisionmakers. ${ }^{17}$ One of our purposes is to adapt this research as an aid to normative constitutional theory.

The second reason for turning to the institutional-design question is that, despite the continuing academic controversy, the institutional-choice question has largely been settled by force of economic, social, and institutional developments. And it has been settled in favor of extensive congressional authority to decide constitutional questions. Although the judiciary can and does review federal statutes for constitutionality, in many domains the realities of modern government ensure that Congress's authority to decide constitutional questions is effectively paramount. Neil Komesar has insisted upon this point, ${ }^{18}$ although constitutional law scholars have largely ignored it, perhaps because it is empirical rather than conceptual.

In the twentieth century, nonjudicial institutions of government have grown much faster than the judiciary; consider that in 1999 the

16. E.g., BUCHANAN \& TULLOCK, supra note 15, at 119-262 (examining these structural choices); GIOVANNI SARTORI, COMPARATIVE CONSTITUTIONAL ENGINEERING passim (2d ed. 1997) (discussing structural choices); Saul Levmore, Bicameralism: When Are Two Decisions Better than One?, 12 INT'L REV. L. \& ECON. 145, 146 (1992) (discussing the relationship between structural choices and decisionmaking).

17. E.g., Donald G. Morgan, Congress and the Constitution: A Study of RESPONSIBILITY passim (1966) (discussing Congress's role in constitutional interpretation); Keith E. Whittington, Constitutional Construction: Divided Powers and Constitutional MEANing passim (1999) (examining how the Constitution operates within the political sphere); Mark C. Miller, Congressional Committees and the Federal Courts: A NeoInstitutional Perspective, 45 W. POL. Q. 949, 949 (1992) (examining the differences in interactions between three congressional committees and the Federal courts).

18. Neil K. Komesar, Imperfect Alternatives: ChoOsing Institutions in LaW, ECONOMICS, AND PUBLIC POLICY 251 (1994). 
total federal judicial budget was $\$ 3.79$ billion, while the administrative budget of the political branches alone ran to some $\$ 80$ billiontwenty-one times larger. ${ }^{19}$ Congress, the White House, and the federal administrative agencies form an institutional system whose current scale and scope-measured by resources, revenue, personnel, outputs, or any other dimension-dwarfs the scale on which courts operate. This disparity ensures that the judiciary lacks the logistical capacity to review more than a small fraction of political-branch decisions, including congressional decisions embodied in statutes that raise constitutional questions. The Court's peak capacity runs to about 150 cases per year, most of which concern statutory interpretation rather than constitutional adjudication, whereas in the past decade Congress has produced an average of about 585 new public laws per year, and administrative agencies have produced thousands of new regulations. ${ }^{20}$ Many of these laws pose no constitutional questions, and to some extent the Court can compensate for its capacity constraints by deciding fewer cases but issuing broader rules in the cases it does decide..$^{21}$ In general, however, the gargantuan congressional-administrative process produces more lawmaking than the comparatively miniscule judiciary has the capacity to review for constitutionality.

So it is unsurprising that the Supreme Court has itself retreated from judicial review of many types of congressional decisions. Consider the following selection of congressional activities and determinations, with important constitutional dimensions, that the federal courts decline to review, either de jure under the rubric of justiciability and political-question doctrines, or de facto under the rubric of rational-basis review:

19. Executive Office of the President, Historical Tables: Budget of the UNITED STATES GOVERNMENT, FISCAL YEAR 2001, at 69 (listing outlays by agencies from 1997 to the present and including estimates through 2005); EXECUTIVE OFFICE OF THE PRESIDENT, Budget of the United States Government: Budget, FisCAL YeAr 2001, at 279 (listing total expenditures of the legislative and executive branches in 1999).

20. U.S. Census Bureau, Statistical Abstract of the U.S. 294 (1999) (listing the number of measures passed by the 96th through 104th Congresses).

21. Richard A. Posner, The Federal Courts: Challenge AND ReForm 369 (1996) (arguing that using rules instead of standards or multi-factor tests may reduce caseloads but cautioning against this approach with regard to constitutional cases). 
- The procedural validity of constitutional amendments; ${ }^{22}$

- The procedural validity of enacted statutes, ${ }^{23}$

- The creation and validity of internal congressional rules, ${ }^{24}$

- "Economic and social" regulation, ${ }^{25}$ a huge category that includes

(1) regulation of the channels and instrumentalities of interstate commerce and of intrastate activity that substantially affects interstate commerce ${ }^{26}$

(2) regulation of property rights, short of a physical appropriation or total deprivation of value, ${ }^{27}$

(3) regulation of contractual obligations, ${ }^{28}$

- Spending for the general welfare, both conditional ${ }^{29}$ and unconditional;

- Use and disposition of the property of the United States; ${ }^{30}$

- Delegation of rulemaking authority to the Executive or to independent agencies, ${ }^{31}$

22. Coleman v. Miller, 307 U.S. 433, 456 (1939) (holding that the validity of ratification by state legislatures is a political question).

23. Field v. Clark, 143 U.S. 649, 673 (1892) (refusing to consider extrinsic evidence to question the enrollment of a bill). But cf. United States v. Munoz-Flores, 495 U.S. 385, 387 (1990) (holding that Origination Clause issues are justiciable).

24. U.S. CONST. art. I, $\S 5$, cl. 2 (authorizing each house of Congress to "determine the Rules of its Proceedings").

25. Williamson v. Lee Optical, Inc., 348 U.S. 483, 487 (1955) (holding that economic and social regulation receives only rational basis review).

26. United States v. Morrison, 529 U.S. 598 (2000) (noting that the federal commerce power extends to the categories in text); United States v. Lopez, 514 U.S. 549, 558-59 (1995) (same).

27. Lucas v. S.C. Coastal Council, 505 U.S. 1003, 1015 (1992) (explaining that a per se taking exists only where there is a physical appropriation or a total deprivation of value).

28. Home Bldg. \& Loan Ass'n v. Blaisdell, 290 U.S. 398, 447 (1934) (holding that where the protective power of a state is exercised in a manner otherwise appropriate in regulating business, it is no objection that performance of existing contracts may be frustrated by the prohibition of injurious practices).

29. South Dakota v. Dole, 483 U.S. 203, 210 (1987) (applying a deferential standard of review to conditions accompanying federal grants of money to subnational governments); Frothingham v. Mellon, 262 U.S. 447, 487 (1923) (denying standing to a citizen seeking to enjoin the Secretary of the Treasury from distributing funds pursuant to the Maternity Act of 1921).

30. Valley Forge Christian Coll. v. Americans United for Separation of Church \& State, Inc., 454 U.S. 464, 482 (1982) (determining that taxpayers lack standing to challenge the government's ability to give real property to religious groups).

31. Loving v. United States, 517 U.S. 748, 773-74 (1996) (upholding a delegation to the President of the power to define aggravating factors that permit imposition of the statutory death penalty in military capital cases); Am. Power \& Light Co. v. SEC, 329 U.S. 90, 104 (1946) (upholding a very broad delegation of the authority to regulate holding companies to an independent agency). Some of the functions of the constitutional nondelegation doctrine have been assumed by canons of statutory construction. See generally Cass R. Sunstein, Nondelegation 
- The division of war powers between Congress and the Executive $;^{32}$

- Establishing rules and regulations for the military; ${ }^{33}$

- Simultaneous service in the legislature and in the Executive $;^{34}$

- The admission and naturalization of aliens, ${ }^{35}$

- Confirmations and impeachments; ${ }^{36}$

- Enforcement of the "Republican Form of Government" Clause. $^{37}$

The Court still reviews federal statutes on constitutional grounds, of course. The important point is that the substantive scope of the unreviewable or largely unreviewed exercises of congressional power together amount to a large slice of the activities of the federal government. Komesar is right about the big picture: by and large, the $\mathrm{Su}$ preme Court has retreated to policing a restricted domain of highly salient individual-rights issues, such as free speech and abortion rights; to occasionally invalidating novel interbranch encroachments in the name of the separation of powers; and to occasionally striking down novel exercises of congressional power in the name of federalism. In other domains, which is to say in a great deal of what government does, Congress is the ultimate arbiter of constitutionality. All the more reason, then, to think far more seriously than the literature

Canons, 67 U. CHI. L. REV. 315 (2000) (arguing that the nondelegation doctrine has not been abandoned and that it has merely been relocated to judicial constructions of federal statutes).

32. Lowry v. Reagan, 676 F. Supp. 333, 340 (D.D.C. 1987) (declining to adjudicate, on political-question grounds, a claim for declaratory and injunctive relief under the War Powers Act). For an analysis of the political-question doctrine's application to foreign affairs and international relations, see Jack L. Goldsmith, The New Formalism in United States Foreign Relations Law, 70 U. COLO. L. REV. 1395, 1402 (1999).

33. Gilligan v. Morgan, 413 U.S. 1, 10 (1973) (noting that the supervision, composition, and training of military forces are committed to the discretion of the political branches).

34. Schlesinger v. Reservists Comm. to Stop the War, 418 U.S. 208, 222-23 (1974) (finding that plaintiffs lacked standing to claim that armed forces reserve membership of members of Congress violated the Constitution).

35. Fiallo v. Bell, 430 U.S. 787, 798-99 (1977) (holding that it was not for the Court to probe the justifications for a legislative decision that preferential status is not warranted for illegitimate children and their natural fathers).

36. Nixon v. United States, 506 U.S. 224, 229-30 (1993) (holding that the Senate had sole discretion to choose impeachment procedures).

37. Pac. States Tel. \& Tel. Co. v. Oregon, 223 U.S. 118, 147-48 (1912) (refusing to consider a republican-form-of-government challenge to the state referendum and initiative process); Luther v. Borden, 48 U.S. 1, 46-47 (1849) (reserving for Congress, rather than the federal courts, the charge of enforcing the Clause). 
has to date about how Congress's internal design can be structured to improve Congress's constitutional performance.

\section{B. Some Assumptions About Legislators' Behavior}

Our concern to improve Congress's constitutional performance assumes that at least some legislators, some of the time, give some decisional weight to reasoned constitutional argument. That premise has been challenged by professedly "realist" strands of political science and public choice, but the challenge rests on empirical presuppositions about legislative behavior that turn out to be untenable.

The starting point is the question what ends legislators pursue. The literature contains three distinct answers to this question. After describing two answers that are, respectively, excessively optimistic and excessively jaundiced, we stake out a third, intermediate position.

1. Legislators Act in the Public Interest. Early discussion of Congress's constitutional performance assumed an optimistic picture of legislator-statesmen who act strictly to promote their understanding of the common good. The public-interest view is the positive counterpart to Burke's trustee model of representation, a normative stance that sees a good representative as one who exercises independent judgment for the common weal, rather than simply acting so as to satisfy constituents' preferences. The public-interest assumption persisted for a remarkably long time in the constitutionallaw literature; something similar underlies Brest's idea of the "conscientious" legislator. But naïve forms of optimism about legislators have today been displaced, in most sectors of the constitutional-law academy, by a far more skeptical account of legislative behavior.

2. Legislators Maximize Their Chances of Reelection, or Personal Gain More Broadly Defined. The technical public-choice literature generally models legislative behavior on the explicit assumption that legislators' sole goal is to maximize their chances of reelection. This is largely a methodological assumption, one dictated by the positivist aspiration of public choice to render testable predictions, which are unattainable without a precise maximand. ${ }^{38}$ As

38. Edward L. Rubin, Beyond Public Choice: Comprehensive Rationality in the Writing and Reading of Statutes, 66 N.Y.U. L. REV. 1, 4 (1991) (examining the theoretical basis and goals of public-choice theory). 
explained below, we think the assumption that legislators act solely to maximize their chances of reelection is clearly mistaken if it is treated as an empirical claim, but we have no quarrel with it as a methodological premise within its proper domain. ${ }^{39}$

But there is also a broader, and looser, strand in the nonformalized political science literature with which we do quarrel. This strand is harder to define; these works, sometimes called "realist," principally share a common atmospheric that describes legislators as maximizing personal gain in a crudely venal sense. All legislative behavior, on this view, is rooted in relatively tangible forms of selfinterest, such as the quests for money, fame, and power; realists typically ignore broader motives, such as personal satisfaction from justified accomplishment or the promotion of ideological goals. Some of this work even suggests that all constitutional discourse within legislatures (and maybe generally) is a sham, a cover for self-regarding motives and tactics. As Ian Shapiro titled a critique of a leading work on deliberative democracy, "Politics Is About Interests and Power."

Despite its hard-headed appeal, the "realist" view either represents a pre-empirical methodological commitment or else turns out to be indefensible. To the extent that it makes an empirical claim, it has been falsified outright by empirical work in mainstream political science. That work advances a third, intermediate view.

\section{Legislators Pursue a Complex Set of Public and Personal} Goals. The optimistic public-interest view and the skeptical realist view both represent implausible extremes. The mainstream view in political science takes a more nuanced view of legislators' motivations. Richard Fenno's classic study found that most legislators pursue a variety of ends simultaneously, trading goals off against one another and giving no goal overriding priority. ${ }^{41}$ Although ensuring reelection is one such goal, along with gaining colleagues' respect, another prominent goal is legislators' desire to promote their vision of the public interest. ${ }^{42}$ Subsequent political science work has confirmed

39. Thus, David Mayhew carefully explains that certain features of legislative behavior may best be explained as if legislators care only about getting reelected. That the premise is methodological, not empirical, has not always been remembered by subsequent public-choice scholars. DAvid R. MAYHEW, CONGREss: THE ElectORAL CONNECTION 45-49 (1974).

40. Ian Shapiro, Enough of Deliberation: Politics Is About Interests and Power, in Deliberative Politics 28 (Stephen Macedo ed., 1999).

41. RiCHARD F. FENNO, JR., CONGRESSMEN IN COMMITTEES passim (1973).

42. Id. at 1 . 
this account. ${ }^{43}$ Reelection is, for most legislators, a necessary means to their preferred goals of influencing public policy for the better and accumulating prestige with colleagues; and it is not the case that legislators will trade everything else to secure reelection. In general, empirical work in mainstream political science describes legislators' diffuse ideology-legislators' beliefs about morals, justice, good public policy, and other intangibles-as a far more powerful determinant of legislative behavior than the realist tradition acknowledges. $^{44}$

In the subsequent discussion, we follow this consensus by assuming that some legislators sometimes treat constitutional argument as one indicator of the "public interest" or "good public policy," which in turn has some weight as against legislators' other interests, goals, and aims. In economic terms, we treat legislators as maximizing a complex utility function, in which constitutional considerations are one argument. This empirical starting point is not necessarily inconsistent with the methodological assumption in the technical publicchoice literature that legislators maximize their chances of reelection in preference to all other aims. Even if solely oriented to reelection, several mechanisms might cause legislators to give some weight to constitutional argument.

First, some constituents might desire a representative who takes constitutional argument seriously, and might punish a representative who appears wholly opportunistic about the Constitution. ${ }^{45}$ Second, there are many legislators who enjoy slack in their agency relation-

43. E.g., John W. Kingdon, Models of Legislative Voting, 39 J. POL. 563, 569-70 (1977) (finding that legislators vote, in part, so as to maximize satisfaction of their constituentindependent policy preferences). See generally JOHN W. KINGDON, CONGRESSMEN's VOTING DECISIONS (3d ed. 1989) (discussing legislators' beliefs about public policy as one determinant of their voting decisions); WILLIAM K. MUIR, JR., LEGISLATURE: CALIFORNIA'S SCHOOL FOR POLITICS 105-37 (1982) (asserting that the nature of politics, among other factors, causes legislators to acquire and share knowledge).

44. James B. Kau \& Paul H. Rubin, Economic and Ideological Factors in Congressional Voting: The 1980 Election, 44 PUB. CHOICE 385, 385 (1984) ("[W]hile economic factors are important in explaining legislation, ideological factors are also important."). See generally JERROLD E. SCHNEIDER, IDEOLOGICAL COALITIONS IN CONGRESS (1979) (analyzing the configurations of congressional coalitions from an ideological perspective).

45. See Mark V. Tushnet, Clarence Thomas: The Constitutional Problems, 63 GEO. WASH. L. REV. 466, 469 (1995) (noting that "a senator may gain political points by being a 'person of principle,' rejecting constituent demands for substantive legislation because it violates the senator's understanding of the constitutional scheme"); $c f$. James B. Kau et al., A General Equilibrium Model of Congressional Voting, 97 Q.J. ECON. 271, 286-87 (1982) (emphasizing that constituent ideology significantly affects legislator behavior); Rubin, supra note 38, at 21 ("[R]eelection maximizing itself does not preclude ideological motivations, because the articulation of an ideological position might be the best way to secure re-election.”). 
ship with constituents, usually because they are from safe districts and reelection is not a serious concern. Even on the public-choice premise, those legislators will shift to pursuing other aims, and one of those aims will be to implement the legislators' conceptions of good public policy, including good constitutional law. Third, constitutional argument is given weight by the "civilizing force of hypocrisy." ${ }^{46}$ Even a wholly self-interested legislator cannot afford to take positions in constitutional argument that are too transparently favorable to his own interests. So legislators who want to invest in credibility will have to adjust their positions to disfavor or disguise their own interests to some degree. Likewise, the pressure to maintain a reputation for consistency will, to some degree, cause even self-interested legislators to adhere to a previously established constitutional position when, in changed circumstances, that position works to the legislator's disadvantage.

But in any event, our project is normative, not (as in the publicchoice literature) predictive. For our purposes, the question is not how legislators' behavior should best be modeled, but rather whether legislative discourse about the Constitution is always strategic rather than sincere. We think the realist account of legislators' behavior is itself unrealistic. The claim that public-regarding discourse within legislatures, including constitutional discourse, is invariably a mask for narrowly defined self-interest verges on incoherence. That view finds it difficult to explain why legislators engage in constitutional discourse in the first place. After all, if everyone mouths constitutional formulae out of self-interest, it is unclear why anyone takes constitutional argument seriously, and thus unclear why there is any audience demand for the empty discourse. The realist account can only be salvaged either by assuming widespread myopia in the audience for constitutional discourse-assuming, in other words, that self-interested constitutional discourse successfully dupes other participants over the long term, the sort of assumption that realists usually reject in other contexts-or else by recourse to recondite theoretical epicycles. ${ }^{47}$ All told, the attempted realist debunking provides a partial corrective to

46. Jon Elster, Alchemies of the Mind: Transmutation and Misrepresentation, 3 LEGAL THEORY 133, 176 (1997).

47. E.g., id. at 152-53 (exploring models in which all speakers disguise self-interest in the language of the public interest, because each speaker fears that some listener will falsely believe that another listener will punish the first listener if the first listener fails to punish the principal speaker for failing to speak in a public-spirited fashion). At this point, it seems to us, any methodological advantages of the self-interest assumption have long since dissipated. 
the excessively optimistic assumptions of the constitutional-law literature but does little damage to the mixed picture presented by the empirical work on legislatures. In what follows, then, we will not concern ourselves unduly with the skeptical position.

\section{Defining “Improvements” in Congress's Constitutional Performance}

Our aim is to propose incremental reforms in the internal design of Congress that will improve its constitutional performance while remaining agnostic among contentious theories of constitutional interpretation, and among controversial views of substantive policy and politics. To that end, we define an "improvement" as a design proposal that produces a net gain when assessed along three dimensions: (1) changes in the cost of constitutional deliberation and decisionmaking by the Congress; (2) changes in the cost of constitutional errors by the Congress, defining error relative to an overlapping consensus of background interpretive theories; and (3) the costs of transition from the current design to the proposed design.

This formulation assumes that these costs are commensurable and that no category of cost has lexical priority. A proposal that might improve both the speed and quality of constitutional decisionmaking, for example, should be rejected if it requires a massive restructuring of Congress's internal operations. Likewise, an easily implemented proposal that might produce a slight decrease in the quality of Congress's constitutional deliberations but would bring enormous savings in decisionmaking costs should be encouraged, not rejected.

1. Decision Costs and Deliberative Benefits. The most striking fact about Congress is its severely constricted agenda. ${ }^{48}$ Despite the enormous growth of congressional staff and the refined specialization of its internal structure, Congress faces tight deliberative constraints of time and information. The paramount legal status of the Constitution does not entail that deliberation over constitutional questions is the most important good that Congress supplies; constitutional decisionmaking is one activity among many. So

48. See generally John W. Kingdon, Agendas, Alternatives, And Public Policies (2d ed. 1995) (discussing the crucial role of agenda setting in modern public policymaking and explaining the realities that limit the agenda space). 
proposals for improvement must account for the opportunity costs of constitutional deliberation.

Deliberation, ${ }^{49}$ however, also provides institutional and process benefits. Deliberation exploits the collective character of legislatures in ways that can, in principle, improve Congress's constitutional performance. ${ }^{50}$ Among the concrete benefits of deliberation are its tendencies to encourage the revelation of private information, to expose extreme, polarized viewpoints to the moderating effect of diverse arguments, ${ }^{51}$ to legitimate outcomes by providing reasons to defeated parties, and to require the articulation of public-spirited justifications for legislators' votes. ${ }^{52}$ The last point emphasizes the civilizing force of hypocrisy. The need to articulate public-regarding rationales requires participants to move away from positions too obviously tailored to their self-interest, and partially commits them to maintain prior positions even in changed circumstances. Norms governing deliberation thus modify actions and outcomes as well as speech.

All of these effects transpose easily to the special case of constitutional deliberation. Private information is useful when constitutional judgments have a substantial factual or instrumental component, as they frequently do. The moderating and legitimating effects of deliberation contract the scope of constitutional argument, focus the issues, and palliate losers. Norms requiring public-oriented justifications force proposals to be tailored to those justifications in ways that forestall the worst excesses of factional oppression. ${ }^{53}$ In addition, deliberation makes congressional decisionmaking more accessible and transparent to the public, which increases accountability of the decisionmakers and may enhance the perceived legitimacy of the outcome.

49. We use "deliberation" to refer to public deliberation in committee and floor debate, on the record and before an audience. Congress, especially its committees, sometimes engages in closed sessions or other forms of nonpublic deliberation, but such cases are not empirically important for our purposes.

50. See generally ANDrei MARMor, EQUALITY AND DEMOCRATIC AUTHORITY (forthcoming 2001) (discussing public deliberation as increasing the legitimacy of public authorities) (on file with the Duke Law Journal).

51. Cass R. Sunstein, Deliberative Trouble? Why Groups Go to Extremes, 110 YALE L.J. 71,75 (2000).

52. James D. Fearon, Deliberation as Discussion, in Deliberative DemocraCy 44, 5356, 63-64 (Jon Elster ed., 1998) (evaluating the role of deliberation in political decisionmaking).

53. Cf. Jonathan R. Macey, Promoting Public-Regarding Legislation Through Statutory Interpretation: An Interest Group Model, 86 CoLUM. L. REV. 223, 265-66 (1986) (recommending an interpretative approach that limits private-interest legislation by holding interest groups to their public-regarding statements). 
To be sure, deliberation also suffers pathologies, quite apart from opportunity costs: it can reduce candor, encourage posturing, trigger herd behavior, and silence dissenters. Yet the alternative to deliberation is simply voting without discussion, a procedure that no modern legislature, and few if any collective bodies generally, would ever adopt. It seems indisputable that, on net, some congressional deliberation on constitutional questions is better than none at all. The real question is not whether deliberation is beneficial, but how much deliberation is optimal. In what follows, we attempt to mold our proposals with a view to maximizing the benefits and minimizing the opportunity costs of congressional deliberation on constitutional questions.

2. Error Costs. Any reference to constitutional "error" presupposes substantive criteria of right and wrong, or good and bad, in constitutional interpretation. Two such criteria dominate the legal literature on Congress's constitutional performance. The first is that the Congress commits error whenever it deviates from the Supreme Court's interpretation of the Constitution. The second is that Congress commits error when it deviates from the outcomes dictated by whatever particular constitutional theory the interpreter holds.

Both of these criteria are unattractive. The first applies to an excessively narrow range of constitutional questions and privileges judicial analysis over other modes of reasoning about constitutional questions. The second overlooks that the aim of an institutional-design project is not to entrench some highly contentious, substantive theory, but rather to suggest consensual improvements-structural proposals that would improve Congress's constitutional performance as judged by any of the leading constitutional approaches. So the best criterion identifies "error" by reference to Congress's skill at using the wide range of sources admissible under all (plausible) interpretive theories, and by reference to Congress's ability to achieve outcomes that all (plausible) theories deem reasonable. The consensual improvements that this criterion identifies are, of course, distinct from the procedural benefits of deliberation previously discussed. The moderating and legitimating effects of deliberation, for example, are valuable even if no consensual improvements can be identified.

The first criterion holds that Congress should take the Constitution to mean whatever the Supreme Court says it means. As defended 
by Larry Alexander and Frederick Schauer, ${ }^{54}$ this view does not assert the implausible interpretive view that the Constitution actually means whatever the Court says. Instead, the point is an institutional one. The primary criterion for good constitutional law, the argument runs, is that it should be clear and stable; clarity and stability in turn require a single, paramount constitutional interpreter; and that interpreter should be the Court.

Alexander and Schauer do not claim that their judicialsupremacy view applies to questions not subject to judicial review. That restriction on the scope of their theory is sensible. Limitations on the judiciary's political reach and logistical capacity create a broad domain of constitutional determinations by the Congress that go unreviewed. What, for example, is the Senate to do when it must decide whether some presidential malfeasance amounts to a high crime or misdemeanor $?^{55}$ The United States Reports do not speak to that question.

The only way to expand the scope of the judicial-supremacy view would be to say that Congress should decide constitutional questions predictively, by guessing how the Court would decide them if it heard them. But this is similar to the "imaginative reconstruction" approach in constitutional law, which asks what the Framers would have done had they known what we know now, ${ }^{56}$ and in statutory interpretation, which asks the same question about the enacting legislators. ${ }^{57}$ In both settings, imaginative reconstruction collapses into substantive decisionmaking, because the best way to figure out what the Framers, or legislators, or Justices would do is to figure out what the best answer is. None of this is to deny that Supreme Court precedents constitute a helpful input into the process of congressional deliberation on constitutional questions. But precedent cannot be the only admissible source of constitutional meaning that Congress may consult, for that

54. Larry Alexander \& Frederick Schauer, On Extrajudicial Constitutional Interpretation, 110 HARV. L. REV. 1359, 1387 (1997) (arguing that people outside the Supreme Court should adopt Chief Justice Hughes's perspective that "[t]he Constitution is what the [Supreme Court] say[s] it is").

55. U.S. ConST. art. II, $\S 4$ ("The President, Vice President and all civil Officers of the United States, shall be removed from Office on Impeachment for, and Conviction of, Treason, Bribery, or other high Crimes and Misdemeanors.").

56. Lawrence Lessig, Fidelity in Translation, 71 TEX. L. REV. 1165, 1268 (1993).

57. William N. Eskridge, JR., Philip A. Frickey \& Elizabeth Garrett, LEGISLATION AND STATUTORY INTERPRETATION 218-20 (2000) (describing this technique in statutory interpretation). 
rule would quite often leave Congress with no constitutional guidance at all.

The rest of the literature tends to posit that Congress errs whenever it arrives at outcomes that deviate from those indicated by some particular substantive account of constitutional interpretation. A list of the current contenders includes, in no particular order, originalintention interpretation, ${ }^{58}$ original-meaning interpretation, ${ }^{59}$ commonlaw constitutionalism, ${ }^{60}$ process theory, ${ }^{61}$ law as integrity, ${ }^{62}$ minimalism, $^{63}$ and pragmatism. ${ }^{64}$ Although some of these are better described as theories of constitutional adjudication than as interpretive theories, and are thus of attenuated relevance to constitutional deliberation by legislators, it is still true that a substantive approach must necessarily elevate one of the contested interpretive accounts over its competitors, despite intractable disagreement among proponents of these views.

By ignoring the phenomenon of chronic disagreement about interpretive theory, this sort of approach creates a serious regress problem for institutional design. Substantive approaches intended to improve congressional deliberation must be addressed to a Congress whose members do not all subscribe to that account, and who would deliberate about the proposals themselves under diverse standards of constitutional evaluation that the members hold. Congress is not an institution noted for facing and resolving fundamental disagreements, let alone abstract fundamental disagreements about constitutional theory.

But Congress is an institution skilled at reaching specific agreements that allow all parties to preserve their abstract commitments. Our approach exploits this institutional strength. We will assess institutional-design proposals in part by their ability to improve Congress's constitutional performance relative to an "overlapping con-

58. RaOul Berger, Government by Judiciary: The Transformation of the FOURTEENTH AMENDMENT 402-10 (2d ed. 1997).

59. Antonin Scalia, A Matter of Interpretation: Federal Courts and the LAW 44-46 (1997).

60. David A. Strauss, Common Law Constitutional Interpretation, 63 U. CHI. L. REV. 877, 884 (1996).

61. ELY, supra note 12, at 14-21.

62. RONALD DWORKIN, LAW'S EMPIRE 95-96 (1986).

63. Cass R. Sunstein, One Case at a Time: Judicial Minimalism on the Supreme COURT 4-5 (1999).

64. Richard A. Posner, The Problems of Jurisprudence 148-54 (1990). 
sensus" ${ }^{65}$ or "incompletely theorized agreement" ${ }^{66}$ about the criteria for successful constitutional argument. Admissible proposals, in other words, should identify improvements that are attractive to proponents of all views.

Such consensual improvements should in principle be available (however difficult they are to identify), because competing accounts of constitutional interpretation display broad overlap along two dimensions: sources and outcomes. All of the major approaches to constitutional interpretation, for example, agree that constitutional text is relevant and admissible, agree that a broad range of potential techniques for interpreting text are barred (interpreters must assume that the text is written in English, that it has public rather than private or coded meaning, and so forth), and that certain other techniques are useful, such as the cautious use of canons of construction. The same is true for precedent, or even more so. Every major approach, even Justice Scalia's originalism, admits precedent as at least a side-constraint on interpretive outcomes, and subscribes to the same hoary collection of common-law techniques for interpreting unclear precedents.

As for outcomes, every interpretive theory professes to subscribe to the small set of precedents that, like Brown v. Board of Education, ${ }^{67}$ have achieved canonical status. But there are also more subtle examples of overlapping consensus on outcomes. Consider the Senate's decision not to censure President Clinton for the behavior on which he was impeached but acquitted. That decision is justified by clause-bound textualism and originalism, which identify conviction or acquittal as the only permissible dispositions of a bill of impeachment, and removal from office as a mandatory sanction upon conviction; ${ }^{68}$ by holistic constitutional interpretation of the law-as-integrity variety, which finds censure offensive to principles underlying the Bill of At-

65. John RaWls, Political Liberalism 133-68 (1993).

66. Such a consensus has been described as follows:

[W] ell-functioning legal systems often tend to adopt a special strategy for producing agreement amidst pluralism. Participants in legal controversies ... agree on the result and on relatively narrow or low-level explanations for it. They need not agree on fundamental principle.... The distinctive feature of this account is that it emphasizes agreement on (relative) particulars rather than on (relative) abstractions.

Cass R. Sunstein, Incompletely Theorized Agreements, 108 HARV. L. REV. 1733, 1735-36 (1995).

67. 347 U.S. 483 (1954).

68. Jack Chaney, The Constitutionality of Censuring the President, 61 OHIO ST. L.J. 979, 1004-12 (2000). But see Joseph Isenbergh, Impeachment and Presidential Immunity from Judicial Process, 18 YALE L. \& PoL'Y REV. 53, 86-93 (1999) (arguing that the Senate may impose lesser sanctions upon conviction). 
tainder Clause and related provisions ${ }^{69}$ and by pragmatism, which points to the potentially damaging consequences of introducing a new weapon, of uncertain potency and application, into the arena of congressional-executive conflict. ${ }^{70}$ If all of the major interpretive approaches agree upon a core set of interpretive sources, skills, and even outcomes, then deliberative "error" can be defined relative to that overlapping consensus without taking sides on fundamental questions. Proposals can be evaluated by their tendency to improve Congress's use of those sources and skills and to improve Congress's ability to deliberate over hard cases, while avoiding outcomes that are condemned by all constitutional approaches.

A serious question about this procedure is that the domain of overlapping consensus might turn out to be too restricted, too banal, to support useful institutional-design proposals. Perhaps the consensus on sources only runs to bromides such as "read the text carefully"; perhaps the consensus on outcomes only bars actions that no wellfunctioning legislature would take anyway. Yet constitutional history provides contrary examples, in which Congress approached a constitutional question in a manner that finds little justification in any of the major interpretive approaches. An unhappy counterpoint to the Clinton impeachment is the impeachment of Andrew Johnson, in which the House preferred charges, and the Senate came within one vote of conviction, based on the constitutionally groundless charge that Johnson had committed a "high" crime by discharging a cabinet secretary. The discharge violated the Tenure of Office Act of 1867, by which the Senate required the President obtain its consent to removals as well as appointments, but there were no respectable textual, originalist, or structural constitutional arguments in the Act's favor, and the Supreme Court later went out of its way to declare it unconstitutional. ${ }^{71}$

The example is extreme. Possibly no institutional-design features could have dampened the House Republicans' impassioned partisanship. Yet the Senate's ultimate decision was in fact the constitutionally correct one, and the example shows that the domain of overlap-

69. Richard A. Posner, Dworkin, Polemics, and the Clinton Impeachment Controversy, 94 Nw. U. L. REV. 1023, 1025-26 (2000).

70. Richard A. Posner, An Affair of State: the Investigation, Impeachment, AND TRial of President Clinton 194-95 (1999).

71. Myers v. United States, 272 U.S. 52, 176 (1926) (holding unconstitutional an 1876 act which denied the President the unrestricted power to remove first-class Postmasters, and stating in dicta that the Tenure of Office Act of 1867 violated the constitution). 
ping constitutional consensus is neither empty nor filled solely by banalities.

3. Transition Costs. The Constitution fixes some features of the design of congressional institutions: bicameralism, ${ }^{72}$ the length of terms in each house, ${ }^{73}$ and the impermissibility of state-imposed term limits $^{74}$ are examples. It also leaves many institutional features unspecified, such as the committee structure, rules governing debate that might allow or restrict the ability to filibuster or amend proposals, the role of political parties in legislative organization, and the size and organization of staff. ${ }^{75}$ In Part II we confine our proposals to small-scale, feasible improvements, rather than large restructurings.

One justification for this restriction is that controversial distributive implications will almost inevitably doom any proposed improvement; minor restructurings, on the other hand, are less likely to inflict large losses on any interested parties, and are thus more likely to gain widespread support. Another justification is that congressional institutions are not infinitely plastic. Large-scale restructurings carry a greater risk of harmful unintended consequences, and even if all goes as planned, the costs of a large-scale transition from one institutional arrangement to another will usually outweigh any gains in reduction of decision costs or error costs. In general, folding in transition costs limits our proposals roughly to the category of internal adjustmentsthat is, adjustments that Congress can make without the consent of any external actor, under the expansive constitutional power of each house to "determine the Rules of its Proceedings."

\section{Is Congress's Constitutional Performance Optimal?}

Even if the institutional-design question is the right one to ask, and even if our three criteria for assessing Congress's constitutional performance are sensible, there remains the possibility that Congress's performance is already optimal. The view would not hold that

72. U.S. CONST. art. I, $\S 1$ (vesting legislative powers in a Congress consisting of the Senate and House of Representatives).

73. U.S. CONST. art. I, § 2, cl. 1 ; id. art. I, § 3, cl. 1 .

74. U.S. Term Limits, Inc. v. Thornton, 514 U.S. 779, 783 (1995).

75. ESKRIDGE, FEREJOHN \& VERMEULE, supra note 57, at 68-69 (describing congressional institutions as falling along a spectrum of durability, with constitutional provisions serving as the most durable).

76. U.S. CONST. art. I, § 5, cl. 2. 
Congress never commits constitutional errors-episodes such as the Johnson impeachment show otherwise-but would rather hold that no cost-justified improvements in congressional performance are possible. This view follows from a simple account of the political incentives that affect congressional deliberation. On this account, opposing legislative coalitions will ventilate opposing constitutional arguments, thereby ensuring fully adequate deliberation. Members who care to do so may raise constitutional concerns during committee deliberations or floor consideration without adopting a special procedure to force such activity.

The view that Congress is optimally designed for constitutional deliberation is surely counterintuitive, and we will argue that it is also false. The final test of whether our proposals represent cost-justified improvements in Congress's procedures for constitutional deliberation is the content of the proposals themselves, described later. But it is worth noting here that the simple account suffers from numerous conceptual and empirical difficulties.

First, the simple account assumes an implicit "fire-alarm" model ${ }^{77}$ of constitutional argument in Congress: coalitions and interest groups monitor proposed bills and sound the alarm when they detect constitutionally troublesome provisions or policies. Only when they hear such an alarm will members of Congress turn their attention to the problem; Congress thereby reduces the costs of monitoring legislative proposals by externalizing those costs onto interested outsiders. But there is no particular reason to believe, a priori, that legislators and interest groups engage in just the right amount of monitoring if they rely on post hoc fire alarms to trigger attention and discussion. To the contrary, the empirical record suggests that Congress, as a collective body that continually adjusts its own rules and procedures over time, often rejects the fire-alarm model in favor of ex ante framework legislation that structures congressional deliberation on constitutional and policy questions.

For a policy example, consider the congressional budget process, a comprehensive framework of procedural and substantive rules enacted by a series of laws, beginning with the Congressional Budget and Impoundment Control Act of $1974^{78}$ and including the Gramm-

77. Cf. Mathew D. McCubbins \& Thomas Schwartz, Congressional Oversight Overlooked: Police Patrols Versus Fire Alarms, 28 AM. J. POL. SCI. 165, 166 (1984) (using a fire-alarm model in the context of congressional oversight of the executive branch agencies).

78. Pub. L. No. 93-344, 88 Stat. 297 (codified at 2 U.S.C. $§ 601$ (1994)). 
Rudman-Hollings Act of $1985,{ }^{79}$ the Budget Enforcement Act of $1990{ }^{80}$ and the Balanced Budget Enforcement Act of $1997 .{ }^{81}$ Taken together, these and related framework statutes structure Congress's fiscal decisionmaking so pervasively that they create something like a fiscal constitution. ${ }^{82}$ For a recent and important example of framework legislation addressed specifically to constitutional questions, consider the Unfunded Mandates Reform Act of 1995 (UMRA), ${ }^{83}$ which requires congressional committees to specify, quantify, and describe any federal mandates that the proposed bill would impose on state, local, and tribal governments and to identify those that are unfunded by the federal government. The UMRA also allows legislators to raise a point of order during floor deliberation in order to focus debate on any unfunded mandate and to require a recorded vote to waive the objection. In addition, the UMRA requires that each House and Senate committee include a statement concerning preemption of state, local, or tribal laws with each reported bill, ${ }^{84}$ in part because of judicial requirements of clear statement and in part to ensure that attention is paid to this constitutional issue.

On this view, the UMRA is best understood as a species of collective precommitment. It represents a judgment by legislators in their collective capacity, outside the divisive context of specific proposals, that fire-alarm monitoring of the federalism questions implicated by unfunded mandates had provided insufficient consideration for constitutional values. The widespread perception of interest groups and lawmakers before passage of the UMRA was that Congress enacted unfunded mandates in some cases without being aware of their existence in an omnibus bill or in ignorance of their scope and effect. $^{85}$

It should not be surprising that legislators sometimes turn to ex ante framework legislation in order to improve congressional per-

79. Balanced Budget and Emergency Deficit Control Act of 1985, Pub. L. No. 99-177, 99 Stat. 1037 (codified as amended at 2 U.S.C. $\$ \S 900-908$ (1994)).

80. Pub. L. No. 101-508, 104 Stat. 1388-573 (codified throughout 2 U.S.C. (1994)).

81. H.R. 898, 105th Cong. (1997).

82. See Kenneth W. Dam, The American Fiscal Constitution, 44 U. CHI. L. REV. 271, 271 (1977) (constructing a general outline of the Amercian fiscal constitution); Kate Stith, Rewriting the Fiscal Constitution: The Case of Gramm-Rudman-Hollings, 76 CAL. L. REV. 593, 599 (1988) (describing the constitutional budget process before and after Gramm-Rudman-Hollings).

83. Pub. L. No. 104-4, 109 Stat. 48.

84. Pub. L. No. 104-4 § 423(e).

85. Elizabeth Garrett, Enhancing the Political Safeguards of Federalism? The Unfunded Mandates Reform Act of 1995, 45 U. KAN. L. REV. 1113, 1150 (1997). 
formance in constitutional settings. Fire-alarm monitoring will be most successful in an arena dominated by organized and sophisticated interest groups on all sides of an issue with clear and established lines of communication to lawmakers with jurisdiction (environmental policy, for example). As with unfunded mandates, however, constitutional issues arise throughout the legislative arena, and affected groups will lack the expertise to discover, analyze, and alert legislators about substantial questions of constitutionality. Therefore, when a constitutional issue arises in an area that does not elicit strong and competing interest-group activity, legislators cannot rely on outsiders to sound the alarm. And as Congress does an increasing share of its work through omnibus legislation, often running into hundreds of provisions and thousands of pages, ignorance of constitutional implications becomes widespread both within Congress and among affected groups.

Furthermore, even when some members are aware of a serious constitutional objection, the chamber's rules may bar public deliberation on the issue. In the House of Representatives, for example, special rules usually structure consideration of legislation and sharply constrain members' ability to raise objections or make amendments. ${ }^{86}$ Increasingly, some major legislation does not receive full consideration by committees before enactment but is instead the product of party task forces, leadership proposals finalized only during the relatively nonpublic conference committee deliberations, or entirely private interbranch summits that produce take-it-or-leave-it proposals that are effectively protected from modification. ${ }^{87}$

Individual legislators could, in principle, address these deficiencies in the fire-alarm system by engaging in individual monitoring or by privately expending the political capital needed to obtain full consideration of constitutional issues. But in other deliberative contexts legislators have responded to the inadequacies of the fire-alarm model through collective action, such as the UMRA, because deliberation within the Congress constitutes a collective good. All legisla-

86. Stanley Bach \& Steven S. Smith, Managing Uncertainty In the House of REPRESENTATIVES: ADAPTATION AND INNOVATION IN SPECIAL RULES 113 (1988).

87. For discussions of these new legislative processes, which are becoming commonplace for major initiatives, see generally JOHN B. GILMOUR, STRATEGIC DisAGREEMENT: STALEMATE IN AMERICAN POLITICS (1995) (discussing strategies of congressional negotiations and advising politicians against stalemate tactics when it would delay helpful legislation); Barbara Sinclair, Unorthodox LaWMAKING: NeW Legislative Processes in the U.S. CONGRESS (2000) (illustrating the contemporary legislative process with various case studies). 
tors benefit when a particular legislator spends time developing information, analyzing constitutional questions, and working with specialized personal staff on constitutional issues. Yet if an individual member provides those benefits, she has taken time away from the tasks that contribute directly to her reelection. She loses time for fundraising, casework, media appearances, and obtaining particularized spending projects in her district; she will thus be at a disadvantage and receive less of the pie of limited federal resources unless all members of Congress spend a similar amount of their time on constitutional issues. If constitutional deliberation is an individually supplied good, individual legislators do not internalize all of the benefits of constitutional deliberation but do shoulder the costs. In such a system, constitutional deliberation will be underproduced.

In the face of the public-good character of constitutional deliberation, all members would benefit from a system that requires lawmakers to allocate some of their scarce time to the consideration of constitutional issues, that provides collective funding for the staff required for this deliberation, and that enforces collective commitments that support deliberation. The constitutional framework we propose, like the UMRA, seeks to solve the collective-action problem and enforce the institutional commitment to spend some time and resources on these matters. Not infinite time and resources, of course; although legislators value a process that provides the opportunity for focused and serious deliberation about difficult constitutional issues, they also have other substantive objectives and value other collective activities. As we have argued, institutional-design proposals must take opportunity costs into account in calibrating the incentives for legislators' deliberation on constitutional questions.

There are few promising alternatives to this sort of ex ante framework legislation. In the constitutional setting, Congress lacks a familiar tool that it often uses to sidestep similar problems in policy settings: delegation to administrative agencies. In areas in which detailed policy expertise is a collective good, one that legislators shirk on supplying to their colleagues, Congress can pass generally worded statutes that delegate policymaking to executive branch agencies. If all members would prefer to promote new technologies that produce clean air at a low cost, but members face collective-action problems in acquiring the expertise necessary to achieve that objective, they can delegate regulatory authority to the Environmental Protection 
Agency - a course of action that, of course, creates new issues in turn. ${ }^{88}$

Delegating the duty to deliberate about and determine constitutional issues is more difficult. In most cases, Congress cannot be sure that affected interest groups will be able to challenge the law in court, or that the Supreme Court will have the capacity and inclination to act as an impartial arbiter of constitutional disagreements between congressional coalitions. There is some evidence that Congress has attempted to delegate certain problematic and controversial constitutional problems to the Supreme Court, through expedited-review provisions that require the Court to take cases attacking the constitutionality of an enactment and to do so early in the judicial process, perhaps before any other appellate review. ${ }^{89}$ This emerging practice has been attacked on a variety of grounds, ${ }^{90}$ for our purposes here, it is enough to observe that the limited capacity of the judicial branch precludes Congress from adopting delegation in the constitutional context as a complete solution to its collective-action problem.

In short, the objection that constitutional deliberation without a collective deliberative structure is optimal-that the fire-alarm model of constitutional objections raised by individual legislators cannot be improved upon-is the same objection heard in the context of other recent structural innovations like the congressional budget process or

88. Broad delegations are the subject of much scholarly and political criticism. E.g., DAVID Schoenbrod, Power Without Responsibility: How Congress Abuses the People Through Delegation passim (1993) (discussing the benefits and costs of delegation and arguing that effective regulation is possible without delegation); Marci A. Hamilton, Representation and Nondelegation: Back to Basics, 20 CARDOZO L. REV. 807 passim (1999) (discussing legislative and executive delegation and arguing that the nondelegation doctrine should be revived). But see Jerry L. Mashaw, Prodelegation: Why Administrators Should Make Political Decisions, 1 J.L. ECON. \& ORG. 81 passim (1985) (arguing that nondelegation critics are misguided); David B. Spence \& Frank Cross, A Public Choice Case for the Administrative State, 89 GEO. L.J. 97 passim (2000) (arguing that agency policymaking is democratically legitimate). Some in Congress advocate adopting a collective framework to improve deliberation about delegations of regulatory authority, sometimes called "private mandates" by those who seek to reduce the number and scope of delegations. E.g., Mandates Information Act of 1999, H.R. 350, 106th Cong., S. 427, 106th Cong. (intended to "improve Congressional deliberation on proposed Federal private sector mandates"); CONGRESSIONAL BUDGET OFFICE, AN AsSESSMENT OF THE UNFUNDED MANDATES REFORM ACT IN 1999, at 14-15 (2000) (discussing proposals that would affect deliberation of private mandates).

89. Line Item Veto Act, 2 U.S.C. § 691d (1994) (repealed in 1998, following Clinton v. City of New York, 524 U.S. 417, 447-49 (1998) (holding that the Line Item Veto Act violated the Presentment Clause by departing from "finely wrought" constitutional procedures for the enactment of law)).

90. E.g., Neal Devins \& Michael A. Fitts, The Triumph of Timing: Raines v. Byrd and the Modern Supreme Court's Attempt to Control Constitutional Confrontations, 86 GEO. L.J. 351, 353-55 (1997) (discussing the importance of delay in maintaining the separation of powers). 
the UMRA..$^{91}$ Members could have passed balanced budgets, or reduced federal spending, or refrained from imposing unfunded mandates, simply by dint of individual effort, without adopting comprehensive deliberative structures. But in all these contexts, members decided that they needed collective precommitments to ensure the production of relevant information and to encourage and channel helpful activity by legislators and interest groups. A realistic picture of Congress, the one to which we subscribe, portrays it as an institution that both engages in substantive deliberation in specific contexts and also has some collective capacity for self-assessment, that struggles over time to adjust its own procedures for constitutional deliberation, and that is willing to consider, in its collective capacity, proposals for deliberative improvement. We advance proposals of that sort in the next part.

\section{LEGISLATIVE RULES OF ADMINISTRATION: DESIGN FEATURES OF A THAYERIAN CONGRESS}

\section{A. Some Principles of Design}

As we describe the design features of a Congress able to discharge its constitutional responsibilities more effectively, we have been guided by four design principles that implement the necessary tradeoffs between decision costs, error costs, and transition costs. First, members of Congress must have adequate information about constitutional issues raised by legislation. They need to know at an early stage when a proposal implicates a significant constitutional issue, and then they require analysis of the substance of the issue. The information should be presented in a way that non-lawyers can understand and that is also accessible for constituents and interest groups. Finally, members may want to develop comprehensive information about congressional consideration of constitutional issues over time, and perhaps also about constitutional implications of laws passed before the adoption of any comprehensive framework, so that they can make ongoing alterations in the new deliberative framework to address gaps or failings.

91. Elizabeth Garrett, Accountability and Restraint: The Federal Budget Process and the Line Item Veto Act, 20 CARDOZO L. REV. 871, 889-90 (1998) (explaining the collective action problem in a budget context); Garrett, supra note 85, at 1132-33 (explaining the problem in the UMRA context). 
Second, members must be afforded an opportunity to raise constitutional issues and to deliberate about them fully. Such opportunities may be most important at the committee level, where information is developed, hearings are held, and sustained and focused discussion among members is possible. But members also need opportunities for focused deliberation of constitutional issues when a bill reaches the floor, especially in the House of Representatives, which usually considers major legislation under closed or modified closed rules denying most members the chance to amend the bill or to raise points of order. Although members will inevitably discuss issues with each other in private settings, the institutional structure should ensure that most debate takes place publicly and is available to members and constituents before final decisions are made.

Third, the institutional design should encourage very broad involvement from experts and interested parties. Members of Congress should be able to receive advice and analysis from the executive branch, representatives of diverse and competing interest groups, and legal experts in the academy and the bar. Such input should be provided in ways that make it accessible to all lawmakers and to the public. Transparent deliberation and accessible information are vital to the way the public views the process; open procedures providing full participation can confer legitimacy on outcomes and encourage public acceptance even among those opposed on the merits. ${ }^{92}$ Congress should also develop internal expertise to assess information provided by outsiders and to produce additional analysis when necessary.

Fourth, the congressional structure for the consideration of constitutional questions should reflect a balance between the need to improve legislative capacity to discharge Congress's responsibility in this area and the need to enact legislation without undue delay or extreme difficulty. Process can produce better legislative outcomes, provide opportunities for transparent debate that allows for congressional accountability, and increase the information available to decisionmakers. Procedures can also be so unwieldy and burdensome that they obstruct the enactment of legislation or provide determined minorities excessive power to delay, kill or modify proposals. Moreover,

92. Cf. Heather J. Smith \& Tom R. Tyler, Justice and Power: When Will Justice Concerns Encourage the Advantaged to Support Policies Which Redistribute Economic Resources and the Disadvantaged to Willingly Obey the Law?, 26 EUR. J. SOC. PSYCH. 171, 173 (1996) (discussing how fair methods and procedures can lead people to sacrifice short-term personal gains in the long-term interest of the greater good). 
process can be used strategically by those unconcerned with constitutional issues to derail bills that they oppose on other grounds.

\section{B. Scope of the Proposals}

Taken as an integrated package, our recommendations produce a set of legislative rules that serve as a Congressional Framework for Constitutional Issues. Before setting out the details of the Framework, one general question is whether the Framework should be limited to the areas of constitutional law in which judicial review is nonexistent or occurs only at the level of rational-basis review ${ }^{93}$ - that is, areas in which Congress is our de jure or de facto final constitutional decisionmaker, as discussed in Part I-or instead should encompass any relevant constitutional questions. We have chosen the latter course, for reasons suggested by the mechanics of, and tradeoffs inherent in, institutional design.

In Part I, we argued that improving Congress's constitutional performance will produce the greatest gains with respect to judicially unreviewed questions of constitutional law. But it is a mistake to assume that the scope of the implementing framework must be precisely tailored to the impetus for proposing it. Across legal domains, the imperatives of institutional design-considerations of decision costs, of the relative attractiveness, in particular settings, of implementation by rules and implementation by standards, and of the reactions of relevant interest groups-cause doctrines to assume a shape that is partially independent of their underlying justifications. In the present setting, as in others, the question is whether the costs of tailoring the Framework more narrowly outweigh the benefits.

The costs of tailoring would be very high. The set of constitutional issues not reviewed by the judicial branch is a constantly evolving list. At some points in our recent history, for example, the courts declined to stringently review cases raising issues of federalism; currently, many (but not all) such cases receive close scrutiny. ${ }^{94}$ Any framework limited in scope to a particular set of identified issues would require constant amendment by Congress to account for changes in judicial practice. If these costs are so high that tailoring

93. See supra notes 22-37 and accompanying text (listing types of controversies in which courts rarely, if ever, intervene).

94. Larry D. Kramer, Putting the Politics Back into the Political Safeguards of Federalism, 100 Colum. L. Rev. 215, 287-93 (2000) (discussing and criticizing the Court's recent attempts to "roll back federal power to what it meant at the Founding"). 
simply proves infeasible, then the choice is an easy one between a general framework for congressional review, on the one hand, and the inadequate level of congressional review that currently obtains, on the other. Even assuming that tailoring is not prohibitively costly, the price is probably not worth paying. It is difficult to identify any substantial costs of a general framework (that is, any serious benefits of tailoring), because the principal effect of a general framework is simply to ensure that both Congress and the judiciary give serious consideration to constitutional issues in domains of legislation subject to judicial review.

To be sure, on a theory of judicial supremacy akin to that of Alexander and Schauer, perhaps congressional consideration of constitutional issues is affirmatively bad. Perhaps vigorous congressional review for constitutionality would even cause the tradition of independent judicial review to atrophy, as judges more frequently defer to congressional decisions or deny standing to parties seeking judicial review. This concern is just the converse of Thayer's concern that aggressive judicial review would cause legislators to evade responsibility for constitutional compliance by passing constitutional questions to the courts.

But the normative and empirical premises of this objection are both dubious. Normatively, most mainstream theories of constitutionalism deem congressional review for constitutionality to be an affirmative good, regardless of the scope of subsequent judicial review. Empirically, the objection at most establishes that the institutional designer must trade off the benefits from a general framework against the possible costs of judicial lassitude in areas previously subject to judicial oversight. That tradeoff cashes out in favor of a general framework for congressional deliberation on constitutional issues, for the reason emphasized in Part I: the domain of effective congressional supremacy, in which a general framework would at least provide some constitutional review (in preference to the inadequate current level), is large and arguably more consequential than the remaining areas of judicial review, in which a general framework might dilute the existing high level of constitutional review. Not only do effectively unreviewed issues form a major part of congressional activity, some laws that implicate constitutional issues on which judicial review is theoretically available may in fact never be reviewed by a court. Perhaps no one will have standing to bring a challenge, or no one with the resources to litigate will be interested in bringing a challenge. Or perhaps the review will take place years after passage, 
leaving a constitutionally problematic law ensconced in the U.S. Code during the interim period.

In sum, the costs of a general framework are both speculative and probably inconsequential, while the benefits of a general framework are impressive. It bears emphasis, however, that it would not be inconsistent with our argument to limit the Framework to the set of constitutional decisions on which judicial review is not available, nor is such a limited procedural framework unprecedented. The UMRA contains a list of exceptions to its coverage which somewhat circumscribes its scope. ${ }^{95}$ In what follows, we will not only set out a general framework, but also glance in passing at design options that might be employed to narrow its scope.

\section{The Congressional Framework for Constitutional Issues}

1. Production and Dissemination of Information. As we explained previously, in some cases, Congress may neglect its responsibility to consider constitutional issues, because members are not aware that a proposal has constitutional ramifications. Relying on a fire-alarm system of review may be insufficiently systematic. Fortunately, models for more regularized notice exist. The most influential and ubiquitous procedural framework designed to produce and structure information is the congressional budget process. ${ }^{96} \mathrm{~A}$ recent addition to the budget rules, the UMRA, requires that the Congressional Budget Office (CBO) provide authorizing committees written statements identifying federal mandates in reported bills. With respect to mandates that exceed certain thresholds, CBO must provide more detailed information about the costs to state and local governments or to the private sector. Similarly, for tax bills, the Joint Tax Committee (JTC) provides revenue estimates for all provisions and tax complexity analyses for provisions with widespread applicability to individuals and businesses. ${ }^{97}$

A modern committee report contains a great deal of mandatory information-some required by budget rules, some by other congres-

95. 2 U.S.C. $\$ 1503$ (1994) (listing seven exceptions including provisions enforcing individual constitutional rights, civil rights laws, emergency laws, and law relating to social security).

96. Elizabeth Garrett, Rethinking the Structures of Decisionmaking in the Federal Budget Process, 35 HARV. J. LEGIS. 387 passim (1998) (describing the effective structuring of current budget decisions).

97. Internal Revenue Service Restructuring and Reform Act of 1998, Pub. L. No. 105-206, 112 Stat. 685, $\S \S 4021-4022$ (1998). 
sional rules-designed to address systematic gaps in information or to provide information to lawmakers who do not serve on the specialized committee and thus might overlook important aspects of policy. ${ }^{98}$ In the House, for example, each committee report contains relevant oversight findings and recommendations made by the Committee on Government Reform, cost estimates (including any new budget authority, spending authority, or changes in tax laws), a statement of the constitutional authority supporting enactment of the bill, an estimate of the costs of any federal mandate on subnational governments, a description and explanation of any such mandate, and a preemption statement. ${ }^{99}$ The Senate Rules require committee reports to include, in addition to the statements required by the UMRA, cost estimates, an evaluation of the numbers of individuals and businesses that would be regulated by the bill, the economic impact of such regulations, a privacy determination, and a statement describing any additional paperwork burdens. ${ }^{100}$

With respect to a similar framework for the consideration of constitutional issues, identifying bills that implicate constitutional questions must occur early so committees with jurisdiction can hold hearings and gather further information about the issue. The parliamentarian, typically a distinguished lawyer with a reputation for nonpartisanship, ${ }^{101}$ can determine at the time of referral to committee whether a proposal appears to raise a significant constitutional issue. The referral decision, which is published in the Congressional Record, can also contain the parliamentarian's description of any constitutional issue. Identification at this time is necessary if a specialized committee will have some role in the deliberation, perhaps through joint or sequential referral, ${ }^{102}$ and it is desirable no matter what committee structure is chosen. For example, an early statement will alert

98. Stephen F. Ross, Legislative Enforcement of Equal Protection, 72 MINN. L. REV. 311, 359 (1987) ("Full disclosure [in committee reports] may prevent legislators with less expertise in the subject area from unconstitutionally supporting the bill or its alternatives without being cognizant of the bill's purpose.").

99. House Committee on Rules (106th Cong.), A PRIMER on CommitTeE RePorts, http://www.house.gov/rules/comm_rep_primer.htm (last visited Apr. 1, 2001) (on file with the Duke Law Journal).

100. S. Doc. No. 106-15 (2000) (listing the standing rules of the Senate regarding committee report requirements), http://www.senate.gov/learning/learn_rules.html\#26 (on file with the Duke Law Journal).

101. DAVID C. King, Turf Wars: How CONGRessional CommitTeEs Claim JURISDICTION 80-85 (1997).

102. See infra notes $132-43$ and accompanying text (discussing various committee structures). 
groups interested in the underlying bill or in the constitutional issue that they should take part in the subsequent deliberations.

In some cases, constitutional issues will arise as the proposal is considered and amended; thus, the trigger for special procedures should occur not only at the initial referral but remain available throughout the committee process. If an issue is identified after bill referral, the parliamentarian will be alerted (and perhaps will amend his referral decision) and a statement identifying the issue will be included in the Congressional Record. The identification process is an ongoing one that proceeds as the bill is refined, reshaped, and rewritten; the failure of the parliamentarian to identify an issue at the outset of its consideration should not be interpreted as a conclusive finding that the bill does not implicate constitutional issues.

Determining what constitutes a "significant" constitutional issue will be tricky; after all, virtually all proposals affect some aspect of the constitutional structure at least marginally. For example, all regulatory statutes raise some element of the nondelegation principle, and many implicate federalism issues. Requiring the parliamentarian to frame the issue he flags in general terms demonstrates the significance of the issue and helps to define it for the committee and staff. In a sense, this issue identification is similar to the Supreme Court's framing of a question on which it grants certiorari, although in the congressional context we expect that the understanding of the issue may change substantially as more information is developed. Unlike the Supreme Court when it deliberates a petition for certiorari, the parliamentarian will have no record of proceedings from other institutions or helpful briefs filed by opposing parties. Instead, he will have only the text of the bill, which is likely to be modified substantially, and perhaps the statement that the member delivered or inserted into the Congressional Record when the bill was introduced.

In addition, the parliamentarian will specifically identify any constitutional issues implicated by the proposal that are issues the judiciary declines to review or reviews only under a rational-basis standard. Such identification will alert members of Congress to their special responsibility with respect to these bills. Initially, the parliamentarian may want to rely on a nonpartisan group of constitutional experts to provide guidelines for this process and to update the list of issues that receive very little or no judicial scrutiny. ${ }^{103}$ Moreover, any ongoing re-

103. MORGAN, supra note 17, at 349 (emphasizing the importance of identifying and defining the constitutional issue and suggesting a bipartisan commission of experts). 
view of the process by expert congressional staff should include assessment of this aspect of the Framework with suggestions for further refinement.

As we will discuss below, additional information will be generated during committee consideration of bills, and in some cases the constitutional issue will become apparent only after some committee work. To provide members the data required for them to make informed decisions when the bill reaches the floor, every bill will be accompanied by a constitutional impact statement. The constitutional impact statement will provide a summary of the committee's findings on the proposal's constitutional implications. If there is no significant constitutional issue raised by the bill, the statement will include that information. The constitutional impact statement will refer to any more comprehensive analyses (perhaps records of public hearings or analyses prepared by expert staff), and it will contain any dissenting views. The constitutional impact statement will be written so that non-lawyers can understand the arguments, not only because many members and most constituents are not lawyers, but also because the institutional strength of Congress is not its attention to legalisms but its expertise in the policy aspects of constitutional decisions. These statements, written by the committee with the assistance of expert staff, ${ }^{104}$ will either be included in the committee report itself or be provided to Congress as soon as practicable after the report is filed. Because conference reports can raise new constitutional issues (although only infrequently because conference committees are formally limited to considering provisions that passed one of the houses or variations on the provisions), staff will also analyze conference reports and include or update constitutional impact statements before floor consideration.

Constitutional impact statements will be more detailed than the parliamentarian's initial framing of the issue. The burden on drafters will not be excessive, however, because statements will be required only with respect to reported bills, a much smaller universe of legislation. The constitutional impact statements should not be boilerplate declarations (as some of the currently required statements in congressional reports have become), except in the case of a finding that the legislation does not implicate a significant constitutional issue. Otherwise, the statement will be a brief summary of the constitutional is-

104. See infra notes 115-28 and accompanying text (discussing the development of expert staff in Congress to deal with constitutional issues). 
sue, together with the committee's views and any dissenting views. If the constitutional issues raised by the proposal are ones that the judiciary declines to review, the statement will identify them as such in order to signal to legislators that their deliberation and decision on these constitutional questions are likely to be the final determinations.

The constitutional impact statements will consolidate and extend some of the other reporting requirements related to constitutional issues. The current requirements for committee reports to include a statement of the constitutional authority for congressional action (in House reports) and to include a statement concerning preemption of state laws (from the UMRA), which are both constitutional statements, will be incorporated into the larger constitutional impact statement. To respond to judicial requirements for clear statements in a number of quasi-constitutional areas, the statements will also declare whether provisions in the bill are severable, identify any retroactive provisions, and provide other clear statements required by the judiciary ${ }^{105}$ a category that may evolve over time as the jurisprudence of interpretive rules of clear statement changes.

Finally, there will be explicit statements declaring whether the legislation allows a pre-implementation challenge to its constitutionality and whether any constitutional challenge receives special or expedited judicial consideration. Recently, statutes like the flag-burning law $^{106}$ and the Line Item Veto Act $^{107}$ have included special provisions to obtain early judicial, and specifically Supreme Court, determinations of constitutional issues, almost like advisory opinions. It appears that these provisions have encouraged lawmakers to shirk their duty to play an active role in constitutional construction and to pass laws about which many have serious doubts in the hope that the courts will correct any errors. ${ }^{108}$ They should therefore be flagged so that they do not escape congressional and public attention.

To ensure that a constitutional impact statement is produced for all legislation, any bill that comes to the floor without such a state-

105. William Eskridge, Jr. \& Philip Frickey, Quasi-Constitutional Law: Clear Statement Rules as Constitutional Lawmaking, 45 VAND. L. REV. 593, 598-611 (1992).

106. Flag Protection Act of 1989, 18 U.S.C. $§ 700$ (1994) (declared unconstitutional in United States v. Eichman, 496 U.S. 310, 319 (1990)).

107. 2 U.S.C. $\S \S 691-692$ (1994) (declared unconstitutional in Clinton v. City of New York, 524 U.S. 417 (1998)).

108. Devins \& Fitts, supra note 90, at 356-57 (describing congressional efforts to expedite Supreme Court review of the constitutionality of the Line Item Veto Act). 
ment will be subject to a point of order, waivable only by a majority vote. $^{109}$ Enforcement is vital. Before the UMRA was enacted, Congress was required to produce fiscal notes containing information on the costs imposed on state and local governments, but that requirement was often ignored or complied with well after floor consideration. ${ }^{110}$ Requiring information without also providing a sanction will result in little information, as members and staff target limited resources on higher priority issues. We will return to the point-of-order enforcement procedures below when we focus on the rules governing floor consideration.

Congress should also require that expert staff produce more comprehensive reports. Annual reports assessing the experience under the new Framework can provide information necessary to adjust the Framework or to improve the deliberative process. Congress produces such assessments of performance under the UMRA, ${ }^{111}$ and the reports aid lawmakers, committee staff, and expert staff in their continuing efforts to interpret vague provisions in the UMRA, to allocate appropriate resources, and to gauge whether the procedure has affected behavior and outcomes. The proposed Federalism Act of 1999, which would expand current requirements for preemption statements and require broader federalism impact assessments, would also require the $\mathrm{CBO}$ to prepare biannual comprehensive assessments of all federal statutes preempting state or local laws. ${ }^{112}$

One aspect of Congress's constitutional performance that all this data ignores is past performance, which may have provided insufficient attention to constitutional issues that will never be reviewed by the judiciary. Most of the procedural frameworks like the UMRA or the congressional budget process are primarily forward-looking; any requirements for reassessments of enacted legislation receive little if any of Congress's limited attention and resources. Although, in a perfect world unaffected by information and other costs, such retrospective analyses would be helpful and might prompt legislative reconsid-

109. See infra notes 150-54 and accompanying text (discussing our point-of-order proposal).

110. Garrett, supra note 85, at 1160-63 (contrasting the fiscal notes process with the UMRA's information requirements and enforcement provisions).

111. See generally CONGRESSIONAL BUDGET OFFICE, supra note 88 (reporting UMRA activity in 1999). Such reports, which are helpful to lawmakers, interest groups, and scholars have been issued every year since the enactment of the UMRA. Id. at iii ("This paper is the fourth annual assessment of the Congressional Budget Office's (CBO's) activities under the Unfunded Mandates Reform Act (UMRA).”).

112. H.R. 2245, 106th Cong. § 10(c) (1999). 
eration, ${ }^{113}$ we believe resources will be more effectively used if directed at future proposals.

2. Expert Congressional Staff on Constitutional Issues. The modern Congress increasingly relies on others to provide information and analysis necessary for decisionmaking, and it will do so in this context as well. Some members of Congress will arrive in Washington with substantial legal knowledge, and some will become experts on constitutional matters during the terms of office. Nevertheless, even learned and sophisticated legal experts in Congress will require help, and most members will depend heavily on others. Some of the information will be produced by interest groups, particularly if early identification of a significant constitutional issue alerts groups to the need for their involvement. Outside production of information does not eliminate the need for internal production, however. First, Congress will need to assess the value of information from parties with a stake in the legislative outcome. Increasingly, even think tanks, which are generally thought of as unaffiliated with particular interest groups although associated with particular ideological commitments, are funded by private entities and used as more neutral-appearing surrogates on Capitol Hill. ${ }^{114}$ Expert staff can analyze information from third parties and use credible information and good arguments in their own work, thereby externalizing some of the information costs. Second, experts can study issues neglected by outside groups, provide balanced perspective in areas where there are not wellmatched competing interest groups, and respond to particular requests by members of Congress.

The idea of creating a body of trained professional staff to help in this area is consistent with larger institutional trends in the legislative branch. Over the last century, as Congress has become more professional and the issues it faces more complex, the number of staff has

113. But see Ruth Bader Ginsburg \& Peter W. Huber, The Intercircuit Committee, 100 HARV. L. REV. 1417, 1430 (1987) (advocating a "system of legislative review and revision under which Congress would take a second look at a law once a court opinion or two highlighted the measure's infirmities").

114. Andrew Rich \& R. Kent Weaver, Advocates and Analysts: Think Tanks and the Politicization of Expertise, in INTEREST GROUP POLITICs 235, 241-42 (Allan J. Cigler \& Burdette A. Loomis eds., 5th ed. 1998) (describing “advocacy tanks"); Dan Morgan, Think Tanks: Corporation's Quiet Weapon, WASH. PosT, Jan. 29, 2000, at A1 (describing undisclosed corporate contributions to think tanks). 
increased substantially. ${ }^{115}$ Moreover, Congress occasionally establishes an internal body of experts to counterbalance expertise in the other branches of government. Thus, Congress created the $\mathrm{CBO}$ so that the legislative branch can deal more successfully with the executive branch, which includes the Office of Management and Budget (OMB) and countless budget experts in the agencies. Frank Easterbrook, among others, has noted that the President often has significant influence on constitutional and other legal matters because he is assisted by the Attorney General, the Solicitor General, their staffs, and the staff of the Office of Legal Counsel. ${ }^{116}$ If Congress wants to step out of the shadows of the judicial and executive branches with regard to constitutional determinations, it must establish an equivalent set of experts.

Although each member could hire a constitutional expert for her staff (and many members already hire lawyers as policy aides), that strategy is a more costly route than setting up an entity like the $\mathrm{CBO}$ or the JTC staff that is funded collectively and that may be able to attract and retain more skilled and better-trained professionals. ${ }^{117} \mathrm{Al}$ ternatively, and particularly if the Judiciary Committees were given jurisdiction over all bills that implicate significant constitutional issues, the staffs of these committees could provide expertise. Individual members might resist this proposal because the staff of the Judiciary Committees is seen as closely tied to the chairs and ranking members of the committees, rather than as resources for the entire Congress. Furthermore, when Congress begins to play a larger role in areas that are viewed by the public as somewhat nonpartisan, members sometimes adopt an institutional framework that allows them to rely on technical experts who are somewhat insulated from the vagaries of politics to produce information that will shape the partisan debate. Such a framework permits lawmakers to gain credibility with

115. In 1972, the total personal and standing committee staff in the House was 5,982; in the Senate the total was 3,061. U.S. CEnsus BuREAU, StATISTICAL AbSTRACT OF THE UNITED STATES 294 (1999). In 1995, the total in the House was 8,432, and in the Senate, the total was 4,979. Id. Those figures do not include expert staff in the CBO, the Congressional Research Service, and other affiliated institutions. $I d$.

116. Frank H. Easterbrook, Presidential Review, 40 CASE W. RES. L. REV. 905, 916-17 (1990).

117. Even if a separate entity is formed to provide expert advice to all members, members may still assign someone in their personal office to focus on constitutional issues. That sort of reaction often occurs so that members can have a trusted agent monitor the credibility of the information they are receiving from congressional actors not so closely aligned with the individual lawmaker's political future. This change is still less costly for members because personal staff perform a monitoring function that requires less expertise and less time. 
constituents because they appear to be basing policy on relatively neutral information. For example, even when JTC revenue estimates made it more difficult for members to pursue policy objectives such as reductions in the capital-gains tax, lawmakers did not fire the staff, nor did they require that the experts use dynamic revenue estimating despite JTC's professional objections to such methodologies. Legislators certainly brought pressure to bear on the technocrats and sought to convince them to alter the assumptions used in their projections. But, frustrated as they were, legislators understood that, on balance, it served members' interests to rely on projections produced by competent and respected economists, rather than solely on information emanating from political operatives. ${ }^{118}$

Many of the expert entities created by Congress reflect an accommodation between the desire to have politics affect the information generated and the need to appear to rely on balanced and relatively nonpartisan data in policymaking. Thus, Congress often adopts an institutional arrangement where the head of the organization is appointed by congressional leaders for discrete terms of office, ${ }^{119}$ but the staff consists mainly of career professionals. Moreover, the interplay of political forces and public deliberation exert some pressure to appoint a more moderate and ideologically balanced director than party leaders might prefer. ${ }^{120}$ But, as with executive branch agencies,

118. Interestingly, the issue of "static" versus dynamic revenue estimating was raised again by Representative Phil Crane in his unsuccessful effort to be named Chair of the Ways and Means Committee. In his campaign, he argued that the Joint Committee had become too independent and nonpartisan, acting more like the CBO or GAO. Warren Rojas, JCT "Static" Scoring Draws Heat from W\&M Chair Candidate, TAX NoTES 1667, 1667 (2000). This rhetoric demonstrates that members view congressional staff as falling along a spectrum of independence.

119. The CBO directors appointed by the Republicans when they took control of the Congress reflected the Republicans' ideology. Eric Pianin, June O'Neill to Depart CBO Early: Embattled Director to Return to Academia, WASH. PosT, Oct. 29, 1998, at A25 (noting that Republicans were unlikely to reappoint O'Neill because she had not made the changes they wanted to help their policy agenda); Alyssa J. Rubin, Congressional Appointments: Conservative O'Neill Is in Line to Run Hill Budget Office, 53 CONG. Q. WKLY. REP. 360, 360 (1995) (noting that the first CBO director appointed by Republicans is "clearly in the conservative camp"). Indeed, one of the appointees, Dan Crippen, was unusual because his background was mainly as a political operative rather than as an economist or public policy expert. George Hager, Former GOP Aide Is Choice to Lead Hill Budget Office, WASH. POST, Jan. 14, 1999, at A25 (describing Crippen's background); Melindah Musa, The Congressional Budget Office in the Federal Budget Process 3 n.11 (Mar. 3, 1999) (describing Crippen as a "seemingly partisan candidate") (unpublished manuscript, on file with the Duke Law Journal).

120. Congressional Budget Office, A Profile of the Congressional Budget OFFICE 13 (1990) (reporting that the appointment of Robert Reischauer was delayed for two years because of heated debate about his ability to be nonpartisan). 
lawmakers can bring political pressure to bear on staff through funding decisions and jawboning. ${ }^{121}$

Different congressional agencies have different reputations for independence. The General Accounting Office and Congressional Research Service (CRS) are often seen as the most independent and neutral $;{ }^{122}$ the CBO and the JTC are seen as more closely affiliated with party leaders although still maintaining a substantial degree of independence and even-handedness; and committee staffs are closely affiliated with politicians and ideology. This diversity of staff leads to more balanced presentation of information. Overlapping responsibilities allow these entities to check each other through a sort of professional competition; ${ }^{123}$ thus, an economist in CRS will produce a report on capital-gains taxes that might call into question the work done by the JTC, and a staff member of the Joint Economic Committee will disseminate a more partisan argument concerning the economic effects of the tax.

There are several options for a structure to provide information to all members of Congress. First, Congress could expand the duties of existing entities and provide additional staff. ${ }^{124}$ For example, each house has an Office of Legal Counsel, established in the 1970s. ${ }^{125}$ The duties of the counsel revolve around representing the House and Senate in court and defending the constitutionality and legality of congressional enactments, subpoenas, and other legislative actions. The Offices of Legislative Counsel assist members in drafting legislation, but currently the counsel do not formally advise lawmakers

121. E.g., Nancy D. Kates et al., Starting from Scratch: Alice Rivlin and the Congressional Budget Office 13-14 (1989) (describing Congress's decision to slash CBO's budget in an attempt to discipline the first director) (on file at the John F. Kennedy School of Government Library, Harvard University).

122. There was a much greater outcry when the Republican Congress appeared to bring partisan pressure to bear on some units of CRS, for example, than when the leadership appointed CBO directors with conservative viewpoints. E.g., Heidi Glenn, Uncertainty Swirls Around CRS Reorganization, 81 TAX NOTES 1455, 1455 (1990) (reporting speculation that the reorganization was done to dilute the Service's analyses after it had issued too many controversial reports).

123. Id. at 1455-56 (describing differences in the entities' responsibilities).

124. A number of states have relatively nonpartisan officials who advise legislators about judicial opinions that affect legislation, drafting, and important legal issues raised by pending or enacted legislation. These offices essentially combine the functions of the federal Offices of Legislative Counsel and the Congressional Research Service and provide additional advice concerning revision and codification. Shirley S. Abrahamson \& Robert L. Hughes, Shall We Dance? Steps for Legislators and Judges in Statutory Interpretation, 75 MiNN. L. REV. 1045, 1061-70 (1991).

125. Charles Tiefer, The Senate and House Counsel Offices: Dilemmas of Representing in Court the Institutional Congressional Client, 61 LAW \& ConTEMP. Probs. 47, 48-49 (Spring 1998). 
about the constitutionality of their proposals, restricting their advice mainly to drafting issues. ${ }^{126}$ To place this new task within the jurisdiction of either of these offices would work a fundamental change in their jobs and require significant additional staff.

The duties of the American Law Division of the Congressional Research Service could be expanded so that the staff would consult more extensively and regularly with Congress on constitutional issues. Now, analysts provide testimony and written analysis when requested; the division functions as a "law office for Congress" with 65 attorneys, paralegals, and support staff. ${ }^{127}$ The option of relying on CRS staff is unlikely to appeal to lawmakers in the context of the new constitutional framework, however. CRS is perceived as an extremely neutral entity with few if any partisan connections (although individual analysts can develop a reputation for particular perspectives associated with political ideologies). Although nonpartisanship is sometimes perceived as an asset, in this context, members are apt to want some closer connection between political considerations and legal ones. Moreover, if it remains separate from any new staff organization, CRS could provide a check on the new staff, which is likely to be more partisan, much as the Government and Finance Division of CRS now provides a check on the economic analyses of the CBO, the JTC, and other congressional committees.

We propose, therefore, that a new congressional office be formed, along the lines of the CBO or the JTC. The Office for Constitutional Issues (OCI) will be headed by a Chief of Staff appointed by some bipartisan group of party leaders. There are several models for the appointments process. For example, the Senate Legal Counsel is responsible to the Joint Leadership Group, which consists of the President pro tempore, the majority and minority leaders, the chair and ranking member of the Judiciary Committee, and the chair and ranking member of the Government Operations Committee. ${ }^{128}$ That group, perhaps without the representatives from Government Opera-

126. MoRGAN, supra note 17, at 358-59 (noting that this practice prevailed in the 1960s).

127. American Law Division Wins ABA Public Service Award, Library of Congress, at http://lcweb.loc.gov/today/pr/1994/94-139 (Aug. 16, 1994) (stating also that from 1989 to 1993, the division processed more than 147,000 inquiries and produced more than 3,200 reports, opinions and analyses) (on file with the Duke Law Journal).

128. The legal counsel in the House, called the General Counsel, is responsible to the Speaker of the House, who then consults with a Bipartisan Legal Advisory Group (including majority and minority leaders) in giving direction to the General Counsel. Rules of the House of Representatives, Rule 2, Other Officers and Officials, available at http://clerkweb.house.gov/ 106/docs/rules/AllRules.htm. 
tions, is well-suited to appoint the head of the OCI. Or, the Chief of Staff of the new constitutional office could be appointed by the Speaker of the House and the President pro tempore, after consultation with the Judiciary Committees, much as the CBO Director is (but there with consultation with the Budget Committees). When the same party controls both houses, this latter process is somewhat less bipartisan than the process used for appointing the Senate Legal Counsel. But, in the CBO-appointment model, party leaders would have as much or more influence over the appointment than committee chairs, a factor which could better ensure responsiveness to the entire body, rather than close affiliation with committees anxious to protect their turfs and possibly consisting of preference outliers.

The staff of the OCI will be appointed in the same way that the CBO appoints its professional staff members. The Chief of Staff will appoint them, including any deputies, and all appointments will be based solely on professional competence, without regard to political affiliation. Much like the CBO and the JTC, the staff will be a mix of lawyers and other professionals and scholars, in this case political scientists, historians, and public policy professionals with interests in constitutional law. Perhaps the Chief of Staff should be an attorney, but that is not clearly the best strategy. The institutional advantage of Congress with regard to constitutional issues is its ability to blend policy considerations with technical legal arguments. Thus, it is important that members receive not only legalistic arguments, but also learn of the broader policy implications of a particular constitutional interpretation relative to others. Lawyers are not always the best professionals to perform this broader sort of analysis. The analyses and reports produced by the staff will be publicly available so that citizens will have access to the information that shapes the constitutional deliberation and decisionmaking of their representatives.

OCI will consult with its counterparts in the executive branch, as CBO staff does with OMB and other agency officials, and as JTC staff does with Treasury and Internal Revenue Service staff. Such consultations will often be largely informal, although it may make sense to formalize some interactions so that they occur as a matter of course and so that the opinions of executive branch experts are available to all members of Congress. ${ }^{129}$ Congress will have to balance the advantage of widespread dissemination of views with the inevitable chilling

129. In some states, legislatures can ask the attorney general for her opinion on the legality of pending legislation. Abrahamson \& Hughes, supra note 124, at 1060. 
effect formal and public disclosure will have. In the tax context, for example, Congress has a mix of formal and informal interactions, with executive branch officials testifying regularly and providing reports and with other staff participating in drafting sessions and informal consultations. OCI should also determine whether its staff or lawmakers will consult formally with members of the judiciary. It seems very unlikely that sitting judges will be comfortable giving their opinions about constitutional issues likely to come before them, ${ }^{130}$ but retired judges may well serve as a source of expertise. Congressional staff should be encouraged to analyze any judicial advice rigorously through the legislative lens, remembering that the legalistic approach of judges may not be as appropriate for Congress. Finally, OCI will no doubt also rely on input and analysis by academics, many of whom will be eager to participate in the process as a way for their ideas and scholarship to shape policies. Scholars will not only be a free and helpful resource for OCI, they will also certainly be available to testify and consult directly with lawmakers.

3. Committee Structure to Consider Constitutional Issues. Those who are skeptical about Congress's capacity to make informed and reflective decisions about constitutional issues point to the relatively low quality of debate on the floors of the House and Senate. Abner Mikva argues: "[B]oth houses are large, making the process of engaging in complex arguments during a floor debate difficult. For the most part, the speeches made on the floor are designed to get a member's position on the record rather than to initiate a dialogue." ${ }^{131}$ This indictment is probably accurate but fundamentally unfair. As Mikva, a former member of Congress, knows, most congressional deliberation does not occur on the floor; it is done in committees. So the relevant-and perhaps the most important-consideration is the committee framework through which such issues are analyzed. There are at least three alternatives for the committee structure of our Congressional Framework for Constitutional Issues.

First, the jurisdiction of the current Judiciary Committees could be expanded so that they would also have responsibility for consid-

130. Robert A. KATZMAnN, Courts And CONGRESS 85 (1997) ("To some degree, courts are hesitant to play a greater role because of constitutional prohibitions against rendering advisory opinions . . . and because of the need to avoid prejudging issues that might come before them.").

131. Abner J. Mikva, How Well Does Congress Support and Defend the Constitution?, 61 N.C. L. REV. 587, 609 (1983). 
ering bills identified at referral or later as implicating significant constitutional issues. The Judiciary Committees would have jurisdiction to consider the constitutional implications of the bill, to work with the OCI to prepare the constitutional impact statement, and to make amendments to the language designed to reflect the constitutional findings. In the House, multiple referral techniques, amended in $1995,{ }^{132}$ would provide the framework for the shared jurisdiction between the substantive committee and the Judiciary Committee. (Of course, in some cases, the Judiciary Committee would also be the substantive committee, and thus its deliberations would include discussions of the substance of the proposal as well as the constitutional issues raised.) The substantive committee would serve as the primary committee, so that when it discharged a bill, Judiciary would have only a limited time period in which to perform its role. The Judiciary Committee could also hold hearings and consider the bill concurrently with the substantive committee's deliberations. Multiple referral occurs less often in the Senate, but it is not unheard of, and it could be structured much like current House procedures. The Judiciary Committees would decide whether to use subcommittees to handle this new responsibility ${ }^{133}$ or to oversee hearings and other preliminary work in the full committee. The recent trend has been away from the use of subcommittees, but it might be a sensible way to handle the additional workload within binding time constraints.

The advantages of using the Judiciary Committees are obvious. These committees already have some expertise in constitutional issues, and they have reputations for relatively serious and careful consideration of legal and constitutional questions. ${ }^{134}$ The disadvantages, however, are substantial, although somewhat less apparent. First, because the committees are composed almost entirely of lawyers, their analyses tend to be legalistic and to replicate what they think judges would say on an issue. They are among the most deferential of lawmakers to courts and traditional legal reasoning. ${ }^{135}$ Second, committee assignments are largely a matter of self-selection, and the lawmakers

132. SINCLAIR, supra note 87 , at $12-13$.

133. The House Committee on the Judiciary has a Subcommittee on the Constitution, and the Senate Judiciary Committee has a Subcommittee on the Constitution, Federalism, and Property Rights.

134. Miller, supra note 17, at 959-61 (describing the Judiciary Committee members' legal experience and their respect for, and deference to, courts).

135. Mark C. Miller, Congress and the Constitution: A Tale of Two Committees, 3 ConsT. L.J. 317, 339-40 (1993). 
who want to serve on the Judiciary Committees tend to be at the extremes of the ideological spectrum. Thus, the Judiciary Committees are often more polarized than other committees and less representative of the body. ${ }^{136}$ Adding significant constitutional issues affecting pending legislation to the committees' portfolios would only exacerbate this tendency, attracting more lawyers with intense preferences on constitutional interpretation. The polarization might affect the committees' deliberations, making compromise less possible and potentially holding up legislation.

It is likely that the substantive committees with primary jurisdiction over legislation subject to our new Framework would vehemently object to sharing power with the Judiciary Committees. ${ }^{137}$ In the budget context, framers discovered that standing committees resisted reallocations of jurisdiction to other existing committees because of turf jealousies. ${ }^{138}$ The solution in the budget arena-creating entirely new committees with little substantive responsibility but with significant power to coordinate the actions of other committees-may well be the best framework for the consideration of constitutional issues and provides the second model of committee organization of the constitutional framework. Just as with the Budget Committees in 1974, Congress has more flexibility in designing new committees and thus can avoid some of the weaknesses of the Judiciary Committees. For example, the rules setting up the new Committees on Constitutional Matters could specify that only a certain number of members could be lawyers, and the rules could require representation from other standing committees (as the House Budget Committee does). It might make some sense to appoint a few members of the Judiciary Committees to the new committees, at least in the early years, to gain from their expertise. To reduce entrenchment on these committees, terms of service could be limited, using the House Budget Committee and the Select Committees on Intelligence as models; term limits would reduce the expertise of the members, however. Because the committees would be new, and thus lack a strong tradition of senior-

136. E.g., Miller, supra note 17 , at $959-60$ (discussing the tendency of House Judiciary Committee members to be ideologically extreme); Ross, supra note 98, at $358 \mathrm{n} .190$ (describing the unrepresentative makeup of the Senate Judiciary Committee).

137. Roger H. Davidson, Congressional Committees in the New Reform Era: From Combat to Contract, in Remaking Congress 28, 48 (James A. Thurber \& Roger H. Davidson eds., 1995) (describing the likelihood of opposition to reform by "[1]eaders and members who suspect[ ] that their committees might be targets for elimination or jurisdictional trimming").

138. Garrett, supra note 96 , at 438 . 
ity in committee assignments, and because they would have farranging jurisdiction affecting many pieces of major legislation, it is likely that party leaders would rely heavily on party loyalty in making appointments and would generally exert more control over committee decisions. That has certainly been the experience with the Budget Committees. ${ }^{139}$

Referrals to these new committees would work in the same way as the first option of using the existing Judiciary Committees. In both cases, committee members would rely on their own committee staff as well as the technical staff of the OCI. Arguably, the rules setting up the OCI should indicate that its primary responsibility is to respond to requests of the committees with jurisdiction over constitutional issues, most importantly to prepare constitutional impact statements and provide related analysis. Responding to inquiries from noncommittee legislators should be the technical staff's second priority. For example, $\mathrm{CBO}$ staff respond in a timely fashion to as many requests as possible from members on and off the Budget Committees. But when time is tight at the end of a session, explicit guidelines allow the expert staff to concentrate their efforts appropriately. If lawmakers decide to establish new committees, they should also consider giving these new committees a role in the selection of the Chief of Staff of the OCI, with the ultimate decision vested with party leaders.

This second option for committee organization has problems, many shared with the first option of giving jurisdiction to the Judiciary Committees. First, members willing to serve on the committees would likely have intense and outlying preferences just as do the current members of the Judiciary Committees. Although party leaders could work to constitute more representative entities, they might find it difficult to convince legislators without intense interest in constitutional issues to spend their time serving on these committees. Now, the Budget Committees are considered prestige committees that are desirable assignments, ${ }^{140}$ but at the outset, some members were reluctant to invest in developing expertise related to a committee that seemed subservient to the appropriations and tax-writing committees. The experience of our new committees might be different from the Budget Committees, however. Originally, the Budget Committees

139. Elizabeth Garrett, The Congressional Budget Process: Strengthening the Party-inGovernment, 100 COLUM. L. REV. 702,715 (2000).

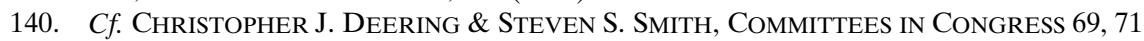
(3d ed. 1997) (noting that limited terms in the House and nonexclusive jurisdiction somewhat reduce the prestige associated with the Budget Committees). 
had very little legislative power; the Committees on Constitutional Matters would have more ability to amend legislation, so they could become powerful more quickly.

Second, situating the constitutional analysis in specialized committees, rather than in the substantive committees that have primary jurisdiction over legislation, would artificially separate constitutional issues from the larger policy issues. Determinations about rights guaranteed by the Constitution are often abstract, and perhaps even meaningless, without simultaneous decisions about how resources will be directed toward vindicating those rights. A poor woman's right to reproductive choice means little to her without the resources to act on her decision; Brown v. Board of Education ${ }^{141}$ resulted in few tangible improvements in education and other facilities until funding was provided, the voting rights acts were passed, and the public commitment to racial equality strengthened. By placing the constitutional inquiry in a different forum from the other consideration of legislation, Congress would signal that it thinks the analyses are capable of clean separation. Furthermore, the advantages to considering constitutional issues along with issues more traditionally considered policy ones would be lost. Pragmatically, it is very difficult to clearly separate the two kinds of issues. Thus, a bifurcated committee structure could cause confusion, duplication, or conflicting messages from the various committees to the full Congress and the public.

The third organizational option, consistent with the design of the UMRA, addresses this problem of separation. Under this model, the substantive committees would perform the constitutional analysis as they considered any bill implicating serious constitutional issues. In most cases, they would know at the time of referral that special constitutional analysis was required. In other cases, awareness of the significant issue would develop as OCI and committee members and staff assessed each active bill in order to draft a constitutional impact statement to accompany the committee report. The committees could determine whether to hold additional hearings on the constitutional issue or to combine that assessment with general hearings on the merits of a proposal. Although members would develop less expertise on constitutional issues than would be the case in the other two models, they could rely on OCI's technical staff, on their own committee counsel, and on lawyers on their personal staff. In addition, individual members might well become more involved in the constitutional is-

141. 347 U.S. 483 (1954). 
sues because of personal preferences (much as occurs now on the generalist tax-writing committees where individual members specialize in agriculture provisions, oil and gas incentives, or other narrow areas), although this development might be unwelcome if the specialists were lawyers who received too much deference to their overly legalistic approaches.

The dynamics of committee consideration would be different if the constitutional assessment were left in the substantive committees rather than placed in specialized committees. First, the substantive committees would likely be less polarized on constitutional issues than the Judiciary or similar committees. Members would have selected the substantive committees because of their interest in the policies that fall within their jurisdiction, and only secondarily (if at all) because of their views on constitutional issues. In other words, members of the Agriculture Committees may have firm positions on farm policy, but they have less intense views on constitutional issues that their bills implicate, such as federalism, the delegation doctrine, or the federal spending power. This characteristic of the substantive committees' membership might allow for more moderated, and perhaps more thoughtful, deliberation. On the other hand, it might mean that constitutional issues would be slighted, because members would not care much about them..$^{142}$ In that case, the attention constitutional issues received would depend on the salience provided by the new Framework and interest-group agitation, the latter a sort of improved fire-alarm mechanism enhanced by the Framework and the information it produces.

Second, the interest-group dynamics would be very different in the substantive committees. Substantive committees attract the attention of groups with stakes in the policies within their jurisdiction. So the members of the Agriculture Committees interact mainly with farm groups, environmental groups, consumer groups, state and local officials with responsibility for farm policy, and others with particular

142. MORGAN, supra note 17, at 352-53 (arguing that substantive committees should not be responsible for the assessment of constitutional issues because they are concerned primarily with "development and effectuation of specialized and often technical policies"). Similar arguments can be found in Miller, supra note 135, at 341-43 (noting that while "Judiciary members and staff undertake sincere efforts to anticipate how the federal courts will read the legislative language produced by the Committee .... [ [substantive] committees are much less concerned about writing legislation that the courts will find constitutional"). We expect that the substantive committees would do a better job deliberating constitutional issues under our proposed system than they do now because they would be able to work with specialized staff and benefit from the work of interest groups that the new Framework prompts. 
interests in agriculture. The committees are monitored primarily by trade publications concerned with farmers, food production, and rural policies. These groups, and their lobbyists, would invest resources in studying constitutional issues, because the new Framework would be another strategic opportunity to affect a bill's fate, but they would not initially possess expertise in such issues. They would invest in developing expertise and producing useful information, because the constitutional Framework would affect the policies adopted by substantive committees. Their information might be particularly helpful because they could infuse their legal analysis with their knowledge of the underlying policies. In contrast, using multiple referrals and specialized committees would mean that the groups with the most sustained interaction with lawmakers on constitutional issues would be those interested in legal issues and constitutional law. Groups like the American Bar Association, the American Civil Liberties Union, the Institute for Justice, and legal academics would exert the primary influence on the deliberations of the Judiciary Committees or the Committees on Constitutional Matters. These groups would have less influence if the constitutional inquiry were done by dozens of substantive committees, because their attention would be fragmented and their resources deployed widely.

The structure of interest-group activity and conflict is a crucial element in committee design. All three options present strengths and weaknesses in this respect. We believe that it would be easier for substantive committees, working with the expert OCI and getting advice from the executive branch and other outside experts, to include the law-oriented interest groups when appropriate than it would be for specialized committees to appropriately blend policy and constitutional law in their deliberations. OCI should adopt guidelines for substantive committees considering bills with significant constitutional implications to encourage them to invite legal experts to testify at hearings or to submit written statements. OCI's formal and informal consultation with expert groups and lawyers in the executive branch would help these interest groups to overcome the problems of fragmentation and to learn of significant constitutional issues in time to weigh in on the outcome. In a sense, the contact entity for the constitutional-law-oriented interest groups would be OCI, which would also serve as a conduit to inform the groups about decisions they want to influence. Substantive interest groups would adapt to the new system by developing their own constitutional impact experts (much as many do now with revenue estimators and budget experts), hiring consult- 
ants specializing in this new aspect of the legislative process, or working in coalitions to cooperate in producing necessary information. Although these costs might be significant, they would often be justified by the benefits offered by the legislation at stake.

As the substantive committees considered the constitutional issues, members and staff would produce studies, analyses, and distillations of others' views. In addition, there would often be public hearings with testimony from staff, officials of other branches, legal experts, and others. ${ }^{143}$ Not only do hearings help inform members and the public, but the openness and wide participation promotes greater citizen involvement in the deliberation and decisionmaking. Issues raised in the hearings would prompt more analysis and alert interested parties to submit additional views. As gaps in coverage appeared during the process, OCI staff could focus their efforts to produce information not submitted by private parties; indeed, they might discover gaps as they did preliminary work to prepare for committee consideration. All the material would be used in the constitutional impact statements and made available to non-committee members and the public.

If a specialized committee model of organization is used, these committees could oversee any annual or more global report prepared by OCI. If the model of substantive committees is selected as we recommend, the OCI comprehensive report could be submitted to the party leadership and made widely available to all members of Congress. For example, the annual assessment of the Unfunded Mandates Reform Act prepared by $\mathrm{CBO}$ is distributed to all members and groups that confer regularly with staff, and it is available on the CBO webpage.

4. Floor Consideration and Points of Order. Procedures structuring floor deliberation seek to balance a number of competing concerns. First, certain structures, notably points of order, reduce the chances that Congress will inadvertently or intentionally ignore difficult or controversial issues, a problem many critics of

143. A good case study for such hearings are those that accompanied enactment of the Religious Freedom Restoration Act. MichaEl A. BAMBERGER, RECKLESS Legislation: How LAWMAKERS IGNORE THE CONSTITUTION 153-66 (2000) (discussing the involvement of legal academics and others in Congress's evaluation of the constitutionality of the RFRA); Michael W. McConnell, Comment, Institutions and Interpretation: A Critique of City of Boerne v. Flores, 111 HARV. L. REV. 153, 160 (1997) (noting that both houses of Congress held public hearings to assist in determining the constitutionality of the proposed act). 
congressional performance in this area have noted. ${ }^{144}$ Even though most members may want to avoid such issues, and the party leaders may work to structure a bill or floor consideration to spare their members difficult votes, ${ }^{145}$ the availability of a point of order can allow one lawmaker (or a few) to halt proceedings, highlight the issue, and force a roll-call vote. Especially in the House, where the floor is tightly controlled by the Rules Committee, a point of order that cannot be waived in a special rule empowers individual members and reduces the chance of success of avoidance techniques. Furthermore, the point-of-order process focuses legislative attention on the constitutional issue and provides the opportunity for sustained debate for which members can be held accountable. Occasionally, constitutional issues identified by a handful of members have been brushed aside during the rush of floor debate and activity. ${ }^{146}$ Points of order make that more difficult.

On the other hand, points of order can be used to stall or derail legislation by lawmakers who oppose the proposal but who do not care about the constitutional issue. In a system of lawmaking like ours, which is full of procedural hurdles, opponents of change, even when they constitute a minority of lawmakers, can strategically use points of order or other rules. ${ }^{147}$ Strategic use of the point-of-order procedure can nonetheless force sincere debate and deliberation about important issues, so the motivation behind the objection may not be relevant in all cases. But as Congress adopts new procedural frameworks, it must be aware that additional process makes enacting laws more difficult. This is particularly true outside the budget context where bills do not have to be passed and the status quo can prevail indefinitely without calamitous consequences such as a government shutdown. Thus, floor procedures must balance the need to allow the opportunity for lawmakers to focus on constitutional issues and the need to enact some legislation.

144. E.g., Mikva, supra note 131, at 609 ("Both institutionally and politically, Congress is designed to pass over the constitutional questions, leaving the hard decisions for the courts.").

145. Barbara Sinclair, Parties in Congress: New Roles and Leadership Trends, in THE Parties Respond: Changes in American Parties And CAMPaigns 299, 312-13 (L. Sandy Maisel ed., 1994).

146. BAMBERGER, supra note 143, at 69 (noting this with respect to the Communications Decency Act and objections brought by Senators Leahy and Feingold).

147. Ross, supra note 98, at 364-65 (discussing the use of constitutional points of order to advance political interests). 
Currently, the Senate allows members to raise constitutional points of order; ${ }^{148}$ the House Rules do not, although representatives have objected to legislation on the ground that it violated the prerogatives of the House under the Origination Clause of the Constitution. ${ }^{149}$ The practice in both houses is that the presiding officer does not rule on the question but instead refers it to the full chamber for a vote. The Framework institutionalizes these points of order, drawing on the experience with other congressional procedural frameworks that are enforced in this way. First, a point of order can be raised by any lawmaker to object to considering a bill that is not accompanied by a constitutional impact statement. Such enforcement is required to ensure that the statements are systematically produced in a timely fashion. Second, a point of order can be raised against any bill with provisions designed to require early judicial determination of constitutional issues. If these provisions encourage Congress to shirk its responsibility to think carefully about constitutional issues, they should be more difficult to include in legislation. Third, a member can raise a point of order against any bill that she believes raises a significant constitutional issue. The information provided in the constitutional impact statements will help alert members to objectionable or worrisome proposals, although members may also discover issues on their own. Importantly, a legislator will not be limited to raising constitutional issues identified initially by the parliamentarian or discussed in the constitutional impact statement.

For this process to be effective in the House of Representatives, the Rules Committee should not be allowed to waive points of order in a special rule, thereby circumventing the objection and recorded vote. ${ }^{150}$ To reduce the strategic use of the third point of order that

148. Floyd M. Riddick \& Alan S. Frumin, Riddick's Senate Procedure 52-54 (1992).

149. Ross, supra note 98, at 359 n.193. This conclusion was confirmed in a phone conversation with a lawyer in the House parliamentarian's office. However, some House precedents suggest that other constitutional points of order may be raised and voted on by the House. E.g., 15 Lewis Deschler \& William Holmes Brown, Deschler-Brown Precedents of THE United States House of Representatives 67-71 (1999) (stating that it is "for the House ... to determine on the constitutionality of the bill").

150. William Holmes Brown, House Practice: A Guide to the Rules, PreCEdents AND Procedures OF THE House 641-42 (1996) (detailing when a point of order may be waived). One of the House parliamentarians stated in a phone conversation that the Rules Committee would never waive a constitutional point of order in a special rule, but such a waiver appears possible under current rules. In addition, a member might well discover a constitutional point of order only after the Rules Committee adopted a closed or modified closed rule which would preclude any objections not identified in the rule itself. 
raises a significant constitutional issue with regard to any bill, a member objecting to consideration of the bill must present to the presiding office a petition signed by twenty members in the House and ten members in the Senate indicating their support for the objection. This innovation is not a feature of any similar congressional framework. The closest analog arises in cloture, where a petition to vote to cut off debate in the Senate must be signed by sixteen senators. ${ }^{151}$ Related but less similar is the rule in the House of Representatives that a majority of the membership can force the discharge of a bill from a committee of jurisdiction. ${ }^{152}$ The requirement in the constitutional context makes the point-of-order strategy more costly to those trying to use it to force changes in the bill, but it still allows a small group of intensely concerned lawmakers to bring the attention of the full body to a constitutional issue.

We favor this design feature because we anticipate that constitutional points of order will arise more frequently than, for example, budget points of order. The latter concern fairly discrete issues (e.g., is an amendment revenue-neutral?) that can be avoided by bill drafters. Constitutional issues, on the other hand, can be raised in more contexts-either sincerely or strategically_and thus pose a more farreaching procedural threat to legislation. This part of the Framework could be modified so that it would provide more protection to bills raising one or more of the constitutional issues that courts decline to review. For example, a single member could be allowed to raise a point of order if the issue were one that courts are unlikely to review (as defined by the parliamentarian advised by the group of legal experts and the OCI staff), and a group of members would be required only with respect to issues that receive robust judicial scrutiny. This modification would increase the complexity of the procedure, but it would tailor the Framework to mirror the greater concern with Congress's deliberation of constitutional issues that are unreviewed by the courts.

Finally, we recommend that only a majority vote be required to waive any of the three points of order. Some budget points of order can be waived in the Senate only by a vote of sixty members, and generally supermajority voting requirements afford greater protection to minority interests than the traditional majority voting rule. Our choice of majority voting rule is driven by our principle of balance-

151. RIDDICK \& FRUMIN, supra note 148, at 283 (restating Senate Rule XXII, II 2).

152. BROWN, supra note 150 , at 433-41. 
the Framework should allow opportunities for deliberation and modification but not halt a great deal of legislative activity. The voting rule may not matter very much in the Senate, because most of this legislation would also be subject to filibusters that can be broken only by a supermajority vote of sixty senators. But lawmakers may be more willing to vote to cut off lengthy debate than to vote against a serious constitutional objection, so it is not clear that the two votes are interchangeable. A supermajority requirement in the House would be a significant new hurdle; no budget point of order in the House requires more than a majority to waive, and only a rule applying to a narrow subset of tax increases is formally enforced through a supermajority voting requirement.

We think a separate vote, which disaggregates the lawmaker's stand on the constitutional issue from her final vote and eliminates or reduces her ability to explain away a troublesome position on the constitutional matter as a necessary evil to passing an omnibus bill with numerous provisions that her constituents like, is sufficient protection. ${ }^{153}$ But rules can be changed, and enforcement procedures calibrated over time to account for experience. Budget rules have changed substantially over nearly three decades as lawmaker objectives have changed and as problems in the process have been identified. For example, the Framework could require supermajority votes in the context of constitutional issues left unreviewed by the judiciary and require only a majority for other constitutional points of order. Furthermore, there may be an advantage to supermajority requirements peculiar to the constitutional realm. Building consensus and demonstrating wide margins of support for constitutional positions may be important for the legitimacy of those determinations. Congress already has a number of formal and informal structures that result in wide margins of victory for most major legislation. ${ }^{154}$ The question is whether an additional supermajority vote would be beneficial, or whether a constitutional determination even by a bare majority of both houses of Congress, already a supermajority requirement, has more legitimacy in the eyes of the public than, for example, a 5-4 decision by the Supreme Court.

153. Ross, supra note 98, at 359-60 (arguing that a "process designed to separate merits from constitutionality" would encourage members to determine the issues in a relatively independent way without allowing their views on the former to bias their constitutional determination and citing examples).

154. TUSHNET, supra note 4 , at 52. 


\section{WHY NOW?}

One final pragmatic question about the Framework remains: why would such a process appeal to members of Congress now? Several factors make this an auspicious time to consider a comprehensive framework to structure deliberation about constitutional issues. The success of the other procedural frameworks encourages this sort of solution for any collective-action problem facing Congress. The budget process is now ubiquitous. No piece of legislation, other than routine and noncontroversial acts, can be considered or enacted without legislators giving some thought to the effect of the budget process. ${ }^{155}$ Congress uses budget reconciliation vehicles several times during a session to pass major policy changes because such acts are insulated from some delay tactics, and other legislation may trigger budget points of order. The UMRA is considered to be such a success that members have floated proposals to expand its coverage. ${ }^{156}$ Indeed, the Republican Congress's concerns about federalism and delegation issues have led to numerous proposals to adopt procedural frameworks intended to shape deliberation in particular ways; process-oriented reform seems to be more popular than enacting substantive reforms directly. ${ }^{157}$ Just as in other institutions, there are elements of path dependence and incrementalism to the reforms adopted by Congress. Members tend to apply familiar tactics to new problems, and they favor expanding old structures or using them as blueprints rather than inventing wholly new approaches. Procedural reforms are in vogue in Congress now. It seems an auspicious time to consider a comprehensive framework that makes incremental progress towards the goal of a Thayerian Congress.

Support for such a framework will come from members who believe they can do a better job when considering constitutional issues,

155. E.g., DEERING \& SMITH, supra note 140, at 193-94 (describing "the ascendance and continuing preeminence of budget politics" as "[t]he most important change in the political agenda during the last two decades"); BURDETT A. LOOMIS, THE CONTEMPORARY CONGRESS 46 (2d ed. 1998) (referring to the "fiscalization" of the entire congressional process brought about by the budget process).

156. E.g., Federalism Act of 1999, H.R. 2245, 106th Cong. §§ 8(b), 10(b) (1999) (requiring the CBO to produce Federalism Impact Statements for all reported bills and to submit annual reports on preemption and requiring the CRS to prepare reports about court decisions affecting federalism); Mandates Information Act of 1999, H.R. 350 \& S. 427, 106th Cong. § 4 (1999) (establishing new procedural hurdles for "private-sector mandates").

157. Federalism, Preemption, and Regulatory Reform (Dec. 21, 2000) (listing proposals that are inspired in part by the UMRA, "the most impressive recent ... enactment," dealing with the constitutional issues), Nat'l Governors Ass'n, http://old.nga.org/106Congress/Federalism.asp (on file with the Duke Law Journal). 
as well as from members or groups in Congress who believe that the Framework will advance other objectives important to them. For example, some of the support for the UMRA surely came from conservative lawmakers who hoped to make it significantly more difficult to pass federal programs and expand the influence of the federal government. Similarly, the budget process, at least since 1985, has systematically worked in favor of those who want to shrink the size of government and erected more obstacles in the way of those who want new spending projects. Whether these small-government types will support the Congressional Framework for Constitutional Issues is unclear. Unlike the current budget process or the UMRA, there is no systematic bias in this Framework; it is apt to be triggered by bills reducing the size of government or supporting politically conservative social policies as often as by bills supported by political liberals. The ex ante neutrality of the Framework may, however, increase rather than decrease its political attractiveness, by precluding opposition from identifiable losers.

Other groups of lawmakers may support the constitutional Framework for reasons other than or in addition to a concern about better deliberation of constitutional issues. Depending on the structure adopted, party leaders may favor adopting the process, because it could shift power away from committees and toward centralized party entities. This shift is most likely if new committees were formed to consider constitutional issues and if party leaders had disproportionate influence over the appointment of the technical staff. However, any process that increases the importance of floor activity for the fate and shape of legislation tends to increase the power of party leaders relative to committee chairs and leaders. ${ }^{158}$ Arguably, members of Congress who are lawyers could become more influential with the adoption of this procedure if other members routinely defer to their opinions about the legal ramifications of legislation. We do not think this would be a desirable outcome.

Note that none of these factors is inconsistent with the diagnosis of a collective-action problem regarding constitutional deliberation, with the case for procedural or accuracy-based benefits of constitutional deliberation, or with the empirical claim that some legislators give some weight to constitutional argument some of the time. They amount to saying that policy entrepreneurs within Congress will benefit, on nonconstitutional dimensions, from advancing framework

158. Garrett, supra note 139, at 722 (making a similar point in the budget context). 
legislation that provides a collective benefit in terms of Congress's constitutional performance. But that is usually, perhaps always, true of resolutions to collective-action problems; self-interested entrepreneurs benefit by satisfying the latent collective demand for a publicly beneficial solution.

\section{CONCLUSION}

Our objective has been to introduce more sustained consideration of institutional-design questions into a discussion that has almost exclusively focused on questions of institutional choice. Whether Congress retains its current role in constitutional interpretation or whether that role is expanded, procedural and institutional devices like those we have described here promise to enhance congressional performance in this arena. A well-functioning Thayerian Congress is one that takes advantage of the lessons learned from modern procedural frameworks to allow it to structure constitutional deliberation and decisionmaking so as to improve outcomes. 